\title{
Synthesis Characterization and Antimicrobial Activity Studies of Some Transition Metal Complexes Derived from 3-Chloro- $N^{\prime}$-[(1E)-(2-hydroxy phenyl)methylene]-6- methoxy-1-benzothiophene-2-carbohydrazide
}

\author{
Vivekanand D. Biradar and B. H. M. Mruthyunjayaswamy \\ Department of Studies and Research in Chemistry, Gulbarga University, Gulbarga-585 106, Karnataka, India \\ Correspondence should be addressed to B. H. M. Mruthyunjayaswamy; bhmmswamy53@rediffmail.com
}

Received 28 August 2013; Accepted 16 September 2013

Academic Editors: E. R. Dockal and D. E. Linn

Copyright ( 2013 V. D. Biradar and B. H. M. Mruthyunjayaswamy. This is an open access article distributed under the Creative Commons Attribution License, which permits unrestricted use, distribution, and reproduction in any medium, provided the original work is properly cited.

\begin{abstract}
A series of new coordination complexes of $\mathrm{Cu}(\mathrm{II}), \mathrm{Co}(\mathrm{II}), \mathrm{Ni}(\mathrm{II}), \mathrm{Zn}(\mathrm{II}), \mathrm{Hg}$ (II), $\mathrm{Mn}$ (II), and $\mathrm{Fe}(\mathrm{III})$ with the Schiff base 3 chloro- $N^{\prime}$-[(1E)-(2-hydroxy phenyl)methylene]-6-methoxy-1-benzothiophene-2-carbohydrazide (HL) have been synthesized and characterized by elemental analysis, electrical conductivity measurements, IR spectra, ${ }^{1} \mathrm{H}$ NMR, mass spectral data, electronic spectra, magnetic susceptibility, ESR spectra, TGA, and Powder XRD data. The Schiff base behaves as tridentate ONO donor ligand and forms the complexes of the type $\mathrm{ML}_{2}$ (metal-ligand) stoichiometry for $\mathrm{Cu}(\mathrm{II}), \mathrm{Co}(\mathrm{II}), \mathrm{Ni}(\mathrm{II})$, and $\mathrm{Mn}$ (II) complexes and $\mathrm{ML}$ stoichiometry for $\mathrm{Zn}(\mathrm{II}), \mathrm{Hg}(\mathrm{II})$, and $\mathrm{Fe}(\mathrm{III})$ complexes. All the complexes are colored and nonelectrolytes. It is found that $\mathrm{Cu}$ (II), $\mathrm{Co}(\mathrm{II}), \mathrm{Ni}(\mathrm{II}), \mathrm{Mn}$ (II) and $\mathrm{Fe}(\mathrm{III})$ complexes have exhibited octahedral geometry whereas $\mathrm{Zn}$ (II) and $\mathrm{Hg}$ (II) complexes exhibited tetrahedral geometry. The ligand and its metal complexes have been screened for their antibacterial activity against $E$. coli and $S$. aureus and antifungal activity against $A$. niger and $A$. flavus.
\end{abstract}

\section{Introduction}

Metal complexes with potentially tridentate and tetradentate ligands have evoked much interest in coordination chemistry [1]. Schiff base complexes of transition metals have played prominent role in the development of coordination chemistry [2]. Several Schiff base metal complexes have been studied because of their industrial and biological applications [35]. Schiff bases containing polyfunctional groups offer many practical advantages and unique structural environment for complexation [6]. Chen et al. [7] have reported $\mathrm{Cu}(\mathrm{II})$ complexes of thiophene-2,5-dicarboxylic acid with a view of constructing diverse low dimensional coordination polymers and the model coordination compounds. Literature survey reveals that many benzothiophene [8-10] derivatives are known to possess good biological activities like antimicrobial, anti-inflammatory, analgesic, diuretic, and antiviral activities.
In view of these findings and in continuation of our research work on coordination chemistry [11-16], we are reporting herewith the synthesis, characterization, and antimicrobial activity of $\mathrm{Cu}(\mathrm{II}), \mathrm{Co}(\mathrm{II}), \mathrm{Ni}(\mathrm{II}), \mathrm{Zn}(\mathrm{II}), \mathrm{Hg}(\mathrm{II})$, $\mathrm{Mn}(\mathrm{II})$, and $\mathrm{Fe}$ (III) complexes of 3-chloro- $N^{\prime}-[(1 E)-(2-$ hydroxy phenyl)methylene]-6-methoxy-1-benzothiophene2-carbohydrazide (HL) (Figure 9) in this communication (H refers to phenolate).

\section{Experimental}

2.1. Material and Method. All the chemicals are of reagent grade. Solvents were dried and distilled before use according to standard procedure [17]. The precursor 3-chloro-6methoxy benzothiophene-2-carbohydrazide was prepared by literature method [18]. The absorption of metal and chloride containt of the complexes were carried out by the standard 
<smiles>CC(O)C(=O)CCC(=O)NN</smiles><smiles>COc1ccc2c(Cl)c(C(=O)N/N=C/c3ccccc3O)sc2c1</smiles>

Scheme 1: Synthesis of ligand HL.

procedure. [19]. The metal chlorides used were in their hydrated form.

2.2. Synthesis of the Ligand HL. An equimolar mixture of 3-chloro-6-methoxy-benzothiophene-2-carbohydrazide $(0.001 \mathrm{~mol})$ and salicylaldehyde $(0.001 \mathrm{~mol})$ in ethanol $(30 \mathrm{~mL})$ was refluxed in presence of catalytic amount of glacial acetic acid (1-2 drops) for about $6 \mathrm{~h}$ on water bath. The reaction mixture was cooled to room temperature, and the separated Schiff base (HL) (Figure 9) was collected by filtration, washed with ethanol, dried and recrystallized from absolute ethanol (Scheme 1).

2.3. Preparation of $\mathrm{Cu}(\mathrm{II}), \mathrm{Co}(\mathrm{II}), \mathrm{Ni}(\mathrm{II}), \mathrm{Zn}(\mathrm{II}), \mathrm{Hg}(\mathrm{II})$, $\mathrm{Mn}(\mathrm{II})$, and $\mathrm{Fe}(\mathrm{III})$ Complexes of Ligand HL. To the hot solution of 3-chloro- $N^{\prime}$-[(IE)-(2-hydroxy phenyl)methylene]-6-methoxy-1-benzothiophene-2-carbohydrazide (HL) (Figure 10) $(0.002 \mathrm{~mol})$ in ethanol $(30 \mathrm{~mL})$ was added a hot ethanolic solution $(10 \mathrm{~mL})$ of respective metal chloride $(0.002 \mathrm{~mol})$; the reaction mixture was refluxed on a steam bath for $4 \mathrm{~h}$, then sodium acetate $(0.5 \mathrm{~g})$ was added to it and refluxed for further $2 \mathrm{~h}$. It was then poured into distilled water. The resulting solid complexes were collected by filtration, washed with sufficient quantity of distilled water, then with hot ethanol to apparent dryness, and dried in a vacuum over anhydrous calcium chloride in a desiccator (Table 1).

2.4. Physical Measurements. IR spectra of the synthesized ligand and its complexes were recorded as $\mathrm{KBr}$ pellets on Perkins-Elmer Spectrum One FT-IR spectrometer. ${ }^{1} \mathrm{H}$ NMR spectra were recorded on a Bruker Avance $400 \mathrm{MHz}$ spectrometer in DMSO using TMS as an internal standard. UVvisible spectra of the complexes were recorded on Elico-SL 164 spectrometer in the range $200-1000 \mathrm{~nm}$ in DMF solution $\left(10^{-3} \mathrm{M}\right)$. Mass spectrum of ligand was acquired on MASPEC system. Elemental analysis was obtained from HERAEUS C, $\mathrm{H}, \mathrm{N}-\mathrm{O}$ rapid analyzer. ESR measurement was carried out on a Bruker BioSpin Gmbh spectrometer working at microwave frequency of $9.903 \mathrm{GHz}$. The experiment was carried out by using diphenylpicrylhydrazyl (DPPH) as reference with field set at 3200 gauss. Magnetic susceptibility was determined by the Faraday method using a model 300 Lewis coil force magnetometer of tesla field strength at room temperature and the instrument was calibrated with $\left[\mathrm{Hg} \mathrm{Co}(\mathrm{SNC})_{4}\right][20]$.

2.5. Antimicrobial Activity. The in vitro biological screening effects of the investigated compounds were tested against the bacterial species $E$. coli and $S$. aureus, fungal species $A$. niger and $A$. flavus by the cup plate method at $1 \mathrm{mg} / \mathrm{mL}$ concentration.

The bacterial and fungal cultures were inoculated in nutrient broth (inoculation medium) and incubated overnight at $37^{\circ} \mathrm{C}$. Inoculated medium containing $24 \mathrm{~h}$ grown culture was added aseptically to the nutrient medium and mixed thoroughly to get a uniform distribution. This solution was poured $(25 \mathrm{~mL}$ in each dish) into Petri dishes and then allowed to attain room temperature. Wells $(6 \mathrm{~mm}$ in diameter) were punched carefully using a sterile cork borer and were filled with test solution $25 \mu \mathrm{L}$. The plates were allowed to stand for an hour in order to facilitate the diffusion of the drug solutions, then the plates were incubated at $37^{\circ} \mathrm{C}$ for $24 \mathrm{~h}$ for bacteria and $48 \mathrm{~h}$ for fungi and the diameter of the zone of inhibition was measured [21]. The results were compared with those of standard drug streptomycin for bacterial and fluconazole for fungal activity of the same concentration as that of the test compounds under identical conditions.

2.6. Antioxidant Activity by DPPH Radical Scavenging Activity. The free radical-scavenging activity of the compounds was measured in terms of hydrogen donating or radical scavenging ability using the stable radical DPPH described by Blois method [22-24]. Briefly, stock solution of the sample $(0.001 \mathrm{~g} / \mathrm{mL})$ was prepared by dissolving it in DMSO. $3 \mathrm{~mL}$ solutions of each with varying concentration $(25-100 \mu \mathrm{g})$ were prepared from the stock solution in methanol. Solution of DPPH $(0.01 \mathrm{mM})$ in methanol was prepared and $1 \mathrm{~mL}$ of this solution was added to the above test solutions. The mixture was shaken vigorously and incubated for $30 \mathrm{~min}$, and then the absorbance was measured at $517 \mathrm{~nm}$. All the tests were run in triplicate and expressed as the mean \pm standard deviation (S.D). Vit-C and Vit-E were used as standard or positive control, parallel to the test compound and in the absence of the test compound/standard used as the negative control. The capability to scavenge the DPPH radical was calculated using the fallowing equation:

$$
\text { Percentage of scavenging activity }=\frac{A_{o}-A_{e}}{A_{o}} \times 100,
$$

where $A_{o}$ corresponds to the absorbance of the negative control that is without sample; $A_{e}$ is the absorbance of sample with complex or ligand.

\section{Results and Discussion}

The physical and analytical data of the synthesized ligand $\mathrm{HL}$ and its $\mathrm{Cu}(\mathrm{II}), \mathrm{Co}(\mathrm{II}), \mathrm{Ni}(\mathrm{II}), \mathrm{Zn}(\mathrm{II}), \mathrm{Hg}(\mathrm{II}), \mathrm{Mn}(\mathrm{II})$, 


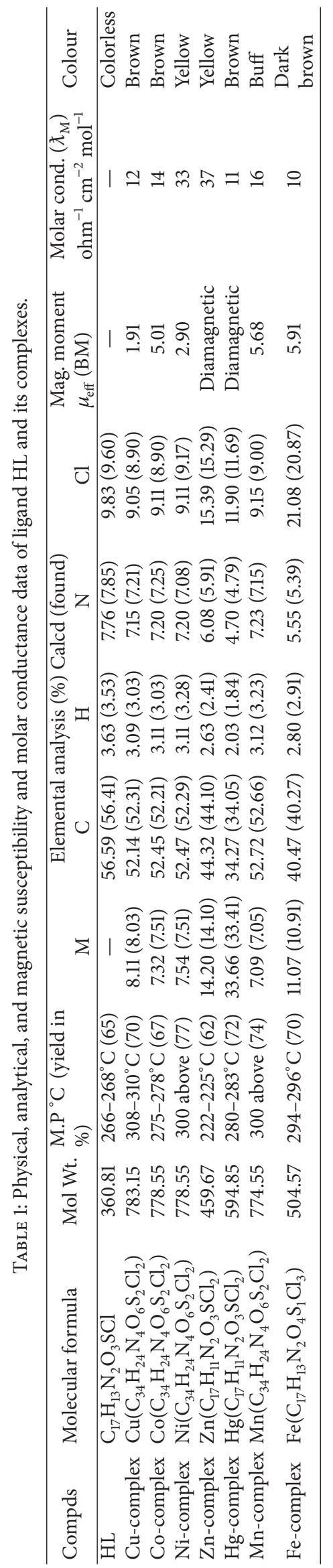


and $\mathrm{Fe}$ (III) complexes are given in Table 1. The molar conductance of the complexes was measured in DMF at $10^{-3} \mathrm{M}$ concentration. Measured conductance values of these complexes are too low to account for their electrolytic behavior.

3.1. IR Spectrum of Ligand HL. In the IR spectrum of the ligand HL, a medium intensity band on $3351 \mathrm{~cm}^{-1}$ is assigned to $v_{\mathrm{NH}}$ vibrations and a sharp band of strong intensity at $1651 \mathrm{~cm}^{-1}$ due to $v_{\mathrm{C}=\mathrm{O}}$ vibration, respectively [25]. A sharp intensity band observed at $1618 \mathrm{~cm}^{-1}$ is assigned to $\nu_{\mathrm{C}=\mathrm{N}}$ vibrations. Presence of intramolecular hydrogen bonded $(\mathrm{O}-\mathrm{H} \ldots \mathrm{N})$ vibration of phenolic $-\mathrm{OH}$ with nitrogen of the azomethine group of the Schiff base [26] is evidenced by the appearance of a broad band at $2901 \mathrm{~cm}^{-1}$. Vibrations because $\mathrm{C}-\mathrm{O}$ was observed at $1235 \mathrm{~cm}^{-1}$. The band due to $\mathrm{C}-\mathrm{S}-\mathrm{C}$ of thiophene ring was found to appear at $1518 \mathrm{~cm}^{-1}$ (Table 2).

3.2. IR Spectra of Cu(II), Co(II), Ni(II), Zn(II), Hg(II), Mn(II), and $\mathrm{Fe}(\mathrm{III})$ Complexes of Ligand HL. Appearance of band in the region $3112-3334 \mathrm{~cm}^{-1}$ in the IR spectra of $\mathrm{Cu}(\mathrm{II}), \mathrm{Co}(\mathrm{II})$, $\mathrm{Ni}(\mathrm{II}), \mathrm{Mn}(\mathrm{II})$, and $\mathrm{Fe}(\mathrm{III})$ complexes of ligand HL is assigned to $v_{\mathrm{NH}}$ of amide function [27]; further appearance of strong intensity bands in the region $1585-1635 \mathrm{~cm}^{-1}$ with a shift in the lower frequency side in these complexes by $16-66 \mathrm{~cm}^{-1}$ when compared to $\mathrm{C}=\mathrm{O}$ of ligand which appear at $1651 \mathrm{~cm}^{-1}$ indicates the involvement of $\mathrm{C}=\mathrm{O}$ oxygen atom in bonding with metal ions as such without undergoing enolization.

But in case of $\mathrm{Zn}$ (II) and $\mathrm{Hg}$ (II) complexes of ligand HL, disappearance of the band due to $\nu_{\mathrm{NH}}$ of amide function [28] and carbonyl function which were found to appear at 3351 and $1651 \mathrm{~cm}^{-1}$, respectively, in case of ligand clearly indicates the enolization of carbonyl function and subsequently coordination of enolized carbonyl oxygen to $\mathrm{Zn}$ (II) and $\mathrm{Hg}$ (II) ion via deprotonation [27]. The fact of enolization of amide function was further conformed by the appearance of a new band (enhanced intensity) in the region $1601 \mathrm{~cm}^{-1}$ in the case of these $\mathrm{Zn}$ (II) and $\mathrm{Hg}$ (II) complexes. Medium intensity band which appeared at $1618 \mathrm{~cm}^{-1}$ in case of ligand HL was found to be shifted to lower frequency side by $58-83 \mathrm{~cm}^{-1}$ and appeared in the region $1535-1560 \mathrm{~cm}^{-1}$ in all these complexes of ligand HL suggesting the coordination of the nitrogen atom of the azomethine function of ligand with metal atoms. In the IR spectra of all these complexes, the absence of band due to intramolecular hydrogen bonded phenolic $\mathrm{OH}$ vibration which appeared at $2901 \mathrm{~cm}^{-1}$ in ligand clearly indicates the deprotonation of hydrogen bonded phenolic $\mathrm{OH}$ group during complexation with metal ions. The band due to phenolic C-O function observed at $1235 \mathrm{~cm}^{-1}$ in case of ligand HL has been found to be shifted to higher frequency side by $83-67 \mathrm{~cm}^{-1}$ in the complexes of the ligand HL under present study and appeared in the region $1302-1318 \mathrm{~cm}^{-1}$, confirms the coordination of phenolic oxygen with the metal ions via deprotonation.

The thiophene ring vibration of the ligand which appeared at $1518 \mathrm{~cm}^{-1}$ in case of ligand remained unaffected in all the complexes and appeared at about the same region
$1501-1535 \mathrm{~cm}^{-1}$ which rules out any possibility of coordination by ring sulphur atom to metal ions.

Assignments in the far IR region are purely tentative because of various skeletal vibrations associated with metal ligand vibrations. The bands of weak intensity $564-505 \mathrm{~cm}^{-1}$ in case of all the complexes of ligand HL are assigned to $v_{\mathrm{M}-\mathrm{O}}$ vibrations. The absorption bands which appeared in the region $455-415 \mathrm{~cm}^{-1}$ in case of all the complexes are assigned to $v_{\mathrm{M}-\mathrm{N}}$ vibrations. In $\mathrm{Zn}(\mathrm{II}), \mathrm{Hg}(\mathrm{II})$, and $\mathrm{Fe}(\mathrm{III})$ complexes ligand HL, new bands observed in the region 315$312 \mathrm{~cm}^{-1}$ are assigned to $v_{\mathrm{M}-\mathrm{Cl}}$ vibrations. The broad band that appeared in the region $3417 \mathrm{~cm}^{-1}$ in case of Fe(III) complexes of ligand $\mathrm{HL}$ is assigned to $\nu_{\mathrm{OH}}$ vibration of the coordinate or lattice water molecules. The IR spectral data of the ligand HL and its complexes are tabulated in Table 2.

\section{3. ${ }^{1} H$ NMR Spectrum of the Ligand HL. The ${ }^{1} \mathrm{H}$ NMR} spectrum (in ppm $\delta$ ) of the ligand HL (Figure 1) which displayed a fine broad singlet observed at $11.21(\mathrm{~s}, 1 \mathrm{H}, \mathrm{OH})$ is assigned to intramolecular hydrogen bonded proton of $\mathrm{OH}$ group with azomethine nitrogen. Another broad singlet observed at $11.20(\mathrm{~s}, 1 \mathrm{H}, \mathrm{CONH})$ is assigned to proton of $\mathrm{CONH}$ function. A sharp singlet at $8.69(\mathrm{~s}, 1 \mathrm{H}, \mathrm{N}=\mathrm{CH})$ is due to azomethine proton. The three protons of methoxy group have resonated as a sharp singlet at $3.82\left(\mathrm{~s}, 3 \mathrm{H}, \mathrm{OCH}_{3}\right)$. Seven aromatic protons have resonated as multiplet in the region of 6.85-7.74 (m, 7H, ArH).

3.4. Mass Spectrum of the Ligand HL. In the mass spectrum of the ligand HL (Figure 2), the molecular ion peak $\mathrm{M}^{+} \cdot$ was observed at $m / z 360,362(96 \%, 33 \%)$. The molecular ion underwent fragmentation to give fragment ions at $m / z 241$, $243(92 \%, 32 \%)$ due to the expulsion of $\mathrm{C}_{7} \mathrm{H}_{5} \mathrm{NO}$ radical from the molecular ion. This fragment ion on further simultaneous loss of CS and HCNO species gave another fragment ion recorded at $m / z 154,156(100 \%, 31 \%)$, which is also a base peak. This fragment ion further loses a chloride radical and gave a fragment ion recorded at $m / z 119$ (3\%), (Scheme 2).

3.5. Electronic Spectra of Cu(II), Co(II), Ni(II), Mn(II), and $\mathrm{Fe}(\mathrm{III})$ Complexes of the Ligand HL. Electronic spectral data of the $\mathrm{Cu}(\mathrm{II}), \mathrm{Co}(\mathrm{II}), \mathrm{Ni}(\mathrm{II}), \mathrm{Mn}$ (II), and Fe(III) complexes of the ligand HL are given in Table 3. Electronic spectral studies of all these complexes were carried out in DMF at $10^{-3} \mathrm{M}$ concentration.

3.5.1. $\mathrm{Cu}$ (II) Complex. The electronic spectrum of $\mathrm{Cu}$ (II) complex derived from the ligand HL showed three bands at 13485, 18728, and $33870 \mathrm{~cm}^{-1}$. Rao et al. [29] has suggested octahedral geometry for $\mathrm{Cu}$ (II) complex due to Schiff base ligand. These complexes displayed a band in the region $13000-19000 \mathrm{~cm}^{-1}$ due to $\mathrm{d}-\mathrm{d}$ transitions. Shashidhara et al. [30] have observed a broad band $15174 \mathrm{~cm}^{-1}$ to $\mathrm{Cu}$ (II) complex which is assigned to ${ }^{2} \mathrm{Eg}-{ }^{2} \mathrm{~T}_{2 \mathrm{~g}}$ and is a characteristic of distorted octahedral geometry. The observed broad band in the case of present $\mathrm{Cu}(\mathrm{II})$ complex of ligand HL can be 
TABLE 2: The IR (in $\mathrm{cm}^{-1}$ ) data of ligand HL and its complexes.

\begin{tabular}{|c|c|c|c|c|c|c|c|c|c|c|c|}
\hline Compds & $\mathrm{NH} / \mathrm{NH}$ & $\begin{array}{c}\mathrm{H} / \mathrm{OH} \\
\mathrm{H}_{2} \mathrm{O}\end{array}$ & $\mathrm{C}=\mathrm{O}$ & $\mathrm{C}=\mathrm{N}$ & $\begin{array}{c}\text { Phenolic } \\
\mathrm{C}-\mathrm{O}\end{array}$ & $\mathrm{C}-\mathrm{S}-\mathrm{C}$ & $\mathrm{C}-\mathrm{O}-\mathrm{C}$ & $>\mathrm{C}=\mathrm{N}-\mathrm{N}=\mathrm{C}<$ & $\mathrm{M}-\mathrm{Cl}$ & $\mathrm{M}-\mathrm{N}$ & $\mathrm{M}-\mathrm{O}$ \\
\hline Ligand HL & 3351 & 2901 & 1651 & 1618 & 1235 & 1518 & 1268 & - & - & - & - \\
\hline $\mathrm{Cu}$-complex & 3267 & - & 1618 & 1535 & 1302 & 1501 & 1268 & - & - & 448 & 564 \\
\hline Co-complex & 3112 & - & 1635 & 1551 & 1317 & 1501 & 1268 & - & - & 445 & 545 \\
\hline Ni-complex & 3351 & - & 1618 & 1560 & 1318 & 1518 & 1269 & - & - & 455 & 510 \\
\hline Zn-complex & - & - & - & 1535 & 1318 & 1535 & 1268 & 1601 & 312 & 418 & 551 \\
\hline Hg-complex & - & - & - & 1551 & 1318 & 1535 & 1268 & 1601 & 315 & 424 & 519 \\
\hline Mn-complex & 3334 & - & 1618 & 1151 & 1314 & 1518 & 1270 & - & - & 415 & 505 \\
\hline Fe-complex & 3317 & 3417 & 1585 & 1551 & 1302 & 1502 & 1268 & - & 314 & 427 & 516 \\
\hline
\end{tabular}

TABLE 3: Electronic and EPR spectral data of complexes of the ligand HL.

\begin{tabular}{|c|c|c|c|c|c|c|c|c|}
\hline \multirow{2}{*}{ Compds } & \multicolumn{4}{|c|}{ Electronic spectral data (in $\mathrm{cm}^{-1}$ ) } & \multicolumn{4}{|c|}{ ESR data } \\
\hline & $v_{1}$ & $v_{2}$ & $v_{3}$ & $v_{4}$ & $g_{\perp}$ & $g_{\mathrm{II}}$ & $g_{\mathrm{av}}$ & G \\
\hline Cu-complex & 13485 & 18728 & - & 33870 & 2.07 & 2.36 & 2.171 & 5.14 \\
\hline Co-complex & 10772 & 15961 & 19511 & - & - & - & - & - \\
\hline Ni-complex & 10590 & 16598 & 25617 & - & - & - & - & - \\
\hline Mn-complex & 17218 & 23435 & 25949 & 31434 & - & - & - & - \\
\hline Fe-complex & 16429 & 20524 & 25635 & - & - & - & - & - \\
\hline
\end{tabular}

assigned ${ }^{2} \mathrm{~B}_{1 \mathrm{~g}} \rightarrow{ }^{2} \mathrm{E}_{\mathrm{g}},{ }^{2} \mathrm{~B}_{2 \mathrm{~g}}$, and ${ }^{2} \mathrm{~A}_{\mathrm{tg}}$ transition suggesting distorted octahedral geometry of $\mathrm{Cu}(\mathrm{II})$ complexes.

3.5.2. $\mathrm{Co}(\mathrm{II})$ Complex. $\mathrm{Co}(\mathrm{II})$ is $\mathrm{d}^{7}$ ion that exists both in octahedral and tetrahedral geometry. In octahedral $\mathrm{Co}$ (II) complexes three spin allowed transitions are expected corresponding to the transitions

$$
\begin{aligned}
& \text { (1) }{ }^{4} \mathrm{~T}_{1 \mathrm{~g}}(\mathrm{~F}) \rightarrow{ }^{4} \mathrm{~T}_{2 \mathrm{~g}}(\mathrm{~F})\left(\nu_{1}\right)\left(\sim 8000 \mathrm{~cm}^{-1}\right) \\
& (2){ }^{4} \mathrm{~T}_{1 \mathrm{~g}}(\mathrm{~F}) \rightarrow{ }^{4} \mathrm{~A}_{2 \mathrm{~g}}(\mathrm{~F})\left(\nu_{2}\right)\left(\sim 16000 \mathrm{~cm}^{-1}\right) \\
& (3){ }^{4} \mathrm{~T}_{1 \mathrm{~g}}(\mathrm{~F}) \rightarrow{ }^{4} \mathrm{~T}_{2 \mathrm{~g}}(\mathrm{P})\left(\nu_{3}\right)\left(\sim 20000 \mathrm{~cm}^{-1}\right)
\end{aligned}
$$

Patel et al. [31] have reported three bands corresponding to $v_{1}, v_{2}$, and $v_{3}$ transition around $9000 \mathrm{~cm}^{-1}, 14500 \mathrm{~cm}^{-1}$, and $20620 \mathrm{~cm}^{-1}$, respectively, for octahedral $\mathrm{Co}$ (II) complex. The Co(II) complex of the ligand HL under present study has showed three bands at $10772 \mathrm{~cm}^{-1}, 15961 \mathrm{~cm}^{-1}$, and $19511 \mathrm{~cm}^{-1}$ due to ${ }^{4} \mathrm{~T}_{1 \mathrm{~g}}(\mathrm{~F}) \rightarrow{ }^{4} \mathrm{~T}_{2 \mathrm{~g}}(\mathrm{~F})\left(\nu_{1}\right),{ }^{4} \mathrm{~T}_{1 \mathrm{~g}}(\mathrm{~F})$ $\rightarrow{ }^{4} \mathrm{~A}_{2 \mathrm{~g}}(\mathrm{~F})\left(v_{2}\right)$, and ${ }^{4} \mathrm{~T}_{1 \mathrm{~g}}(\mathrm{~F}) \rightarrow{ }^{4} \mathrm{~T}_{2 \mathrm{~g}}(\mathrm{P})\left(\nu_{3}\right)$ transition, respectively. These transitions suggest octahedral geometry for $\mathrm{Co}(\mathrm{II})$ complex.

3.5.3. Ni(II) Complex. The ground state of $\mathrm{Ni}(\mathrm{II})$ in octahedral coordination is ${ }^{3} \mathrm{~A}_{2 \mathrm{~g}}\left(\mathrm{t}_{2 \mathrm{~g}}{ }^{6} \mathrm{eg}^{2}\right)$. The $\mathrm{Ni}(\mathrm{II})$ complex shows three transitions in an octahedral field, namely,

$$
\begin{aligned}
& { }^{3} \mathrm{~A}_{2 \mathrm{~g}}(\mathrm{~F}) \rightarrow{ }^{3} \mathrm{~T}_{2 \mathrm{~g}}(\mathrm{~F})\left(\nu_{1}\right)\left(7000-13000 \mathrm{~cm}^{-1}\right) \\
& { }^{3} \mathrm{~A}_{2 \mathrm{~g}}(\mathrm{~F}) \rightarrow{ }^{3} \mathrm{~T}_{1 \mathrm{~g}}(\mathrm{~F})\left(\nu_{2}\right)\left(11000-20000 \mathrm{~cm}^{-1}\right) \\
& { }^{3} \mathrm{~A}_{2 \mathrm{~g}}(\mathrm{~F}) \rightarrow{ }^{3} \mathrm{~T}_{1 \mathrm{~g}}(\mathrm{P})\left(\nu_{3}\right)\left(20000-27000 \mathrm{~cm}^{-1}\right) .
\end{aligned}
$$

The bands in the region $\sim 10000, \sim 12000$, and $25000 \mathrm{~cm}^{-13} \mathrm{~A}_{2 \mathrm{~g}}(\mathrm{~F}) \rightarrow{ }^{3} \mathrm{~T}_{1 \mathrm{~g}}(\mathrm{P})\left(\nu_{3}\right),{ }^{3} \mathrm{~A}_{2 \mathrm{~g}}(\mathrm{~F}) \rightarrow{ }^{3} \mathrm{~T}_{1 \mathrm{~g}}(\mathrm{~F})$ $\left(v_{2}\right)$, and ${ }^{3} \mathrm{~A}_{2 \mathrm{~g}}(\mathrm{~F}) \longrightarrow{ }^{3} \mathrm{~T}_{2 \mathrm{~g}}(\mathrm{~F})\left(\nu_{1}\right)$ for the transitions mentioned above are characteristics of octahedral geometry.

The electronic spectrum of $\mathrm{Ni}$ (II) complex of the ligand HL under present investigation exhibited three bands in the region $10590 \mathrm{~cm}^{-1}, 16598 \mathrm{~cm}^{-1}$, and $25617 \mathrm{~cm}^{-1}$ which are assigned to ${ }^{3} \mathrm{~A}_{2 \mathrm{~g}}(\mathrm{~F}) \longrightarrow{ }^{3} \mathrm{~T}_{2 \mathrm{~g}}(\mathrm{~F})\left(\nu_{1}\right),{ }^{3} \mathrm{~A}_{2 \mathrm{~g}}(\mathrm{~F}) \longrightarrow{ }^{3} \mathrm{~T}_{1 \mathrm{~g}}(\mathrm{~F})$ $\left(v_{2}\right)$, and ${ }^{3} \mathrm{~A}_{2 \mathrm{~g}}(\mathrm{~F}) \longrightarrow{ }^{3} \mathrm{~T}_{1 \mathrm{~g}}(\mathrm{P})\left(v_{3}\right)$ transition. All these observations favor the octahedral geometry for $\mathrm{Ni}$ (II) complex of the present study.

3.5.4. $\mathrm{Mn}$ (II) Complex. The ground term of $\mathrm{Mn}$ (II) ion is in the sextet. The only sextet term of the $\mathrm{d}^{5}$ configuration in octahedral stereochemistry is the ${ }^{6} \mathrm{~A}_{1 \mathrm{~g}}$. The transitions of the spectrum are assigned as from the ${ }^{6} \mathrm{~A}_{1 \mathrm{~g}}$ ground term to the quartet excited term. Electronic absorption spectra of $\mathrm{Mn}$ (II) octahedral complex are expected to show four spin allowed transitions. The four narrow absorption bands approximately around $18000 \mathrm{~cm}^{-1}, 24750 \mathrm{~cm}^{-1}, 29500 \mathrm{~cm}^{-1}$, and $31900 \mathrm{~cm}^{-1}$ were assigned to ${ }^{6} \mathrm{~A}_{1 \mathrm{~g}} \longrightarrow{ }^{4} \mathrm{~T}_{1 \mathrm{~g}}\left({ }^{4} \mathrm{G}\right)\left(\nu_{1}\right),{ }^{6} \mathrm{~A}_{1 \mathrm{~g}} \longrightarrow{ }^{4} \mathrm{E}_{\mathrm{g}}\left({ }^{4} \mathrm{G}\right)$ $\left(v_{2}\right),{ }^{6} \mathrm{~A}_{1 \mathrm{~g}} \longrightarrow{ }^{4} \mathrm{E}_{\mathrm{g}}\left({ }^{4} \mathrm{D}\right)\left(v_{3}\right)$, and ${ }^{6} \mathrm{~A}_{1 \mathrm{~g}} \longrightarrow{ }^{4} \mathrm{~T}_{1 \mathrm{~g}}\left({ }^{4} \mathrm{P}\right)$ $\left(v_{4}\right)$ transitions, respectively, for octahedral $\mathrm{Mn}$ (II) complex [32]. The $\mathrm{Mn}$ (II) complex of the ligand HL under present study has exhibited four absorption bands at 17218, 23435, 25949 , and $31434 \mathrm{~cm}^{-1}$, which corresponds to $v_{1}, v_{2}, v_{3}$, and $v_{4}$ transitions, respectively, suggesting octahedral geometry for the Mn(II) complex.

3.5.5. $\mathrm{Fe}$ (III) complex. The electronic spectrum of $\mathrm{Fe}(\mathrm{III})$ complex displays three bands at 16429, 20524, and 
HL(H1 in DMSO.d6 + CDCL3 mix.)

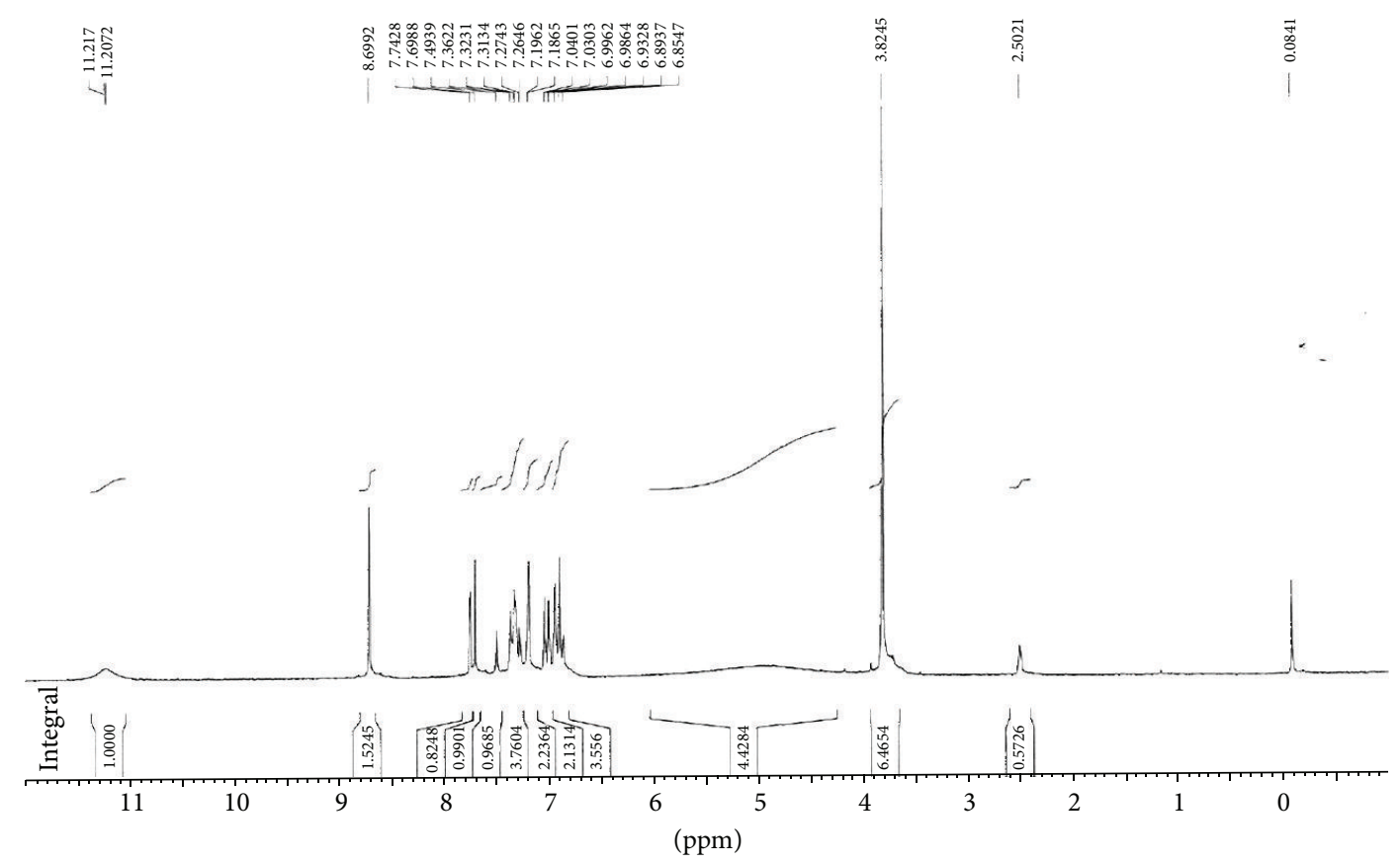

FIGURE 1: ${ }^{1} \mathrm{H}$ NMR spectrum of ligand HL.

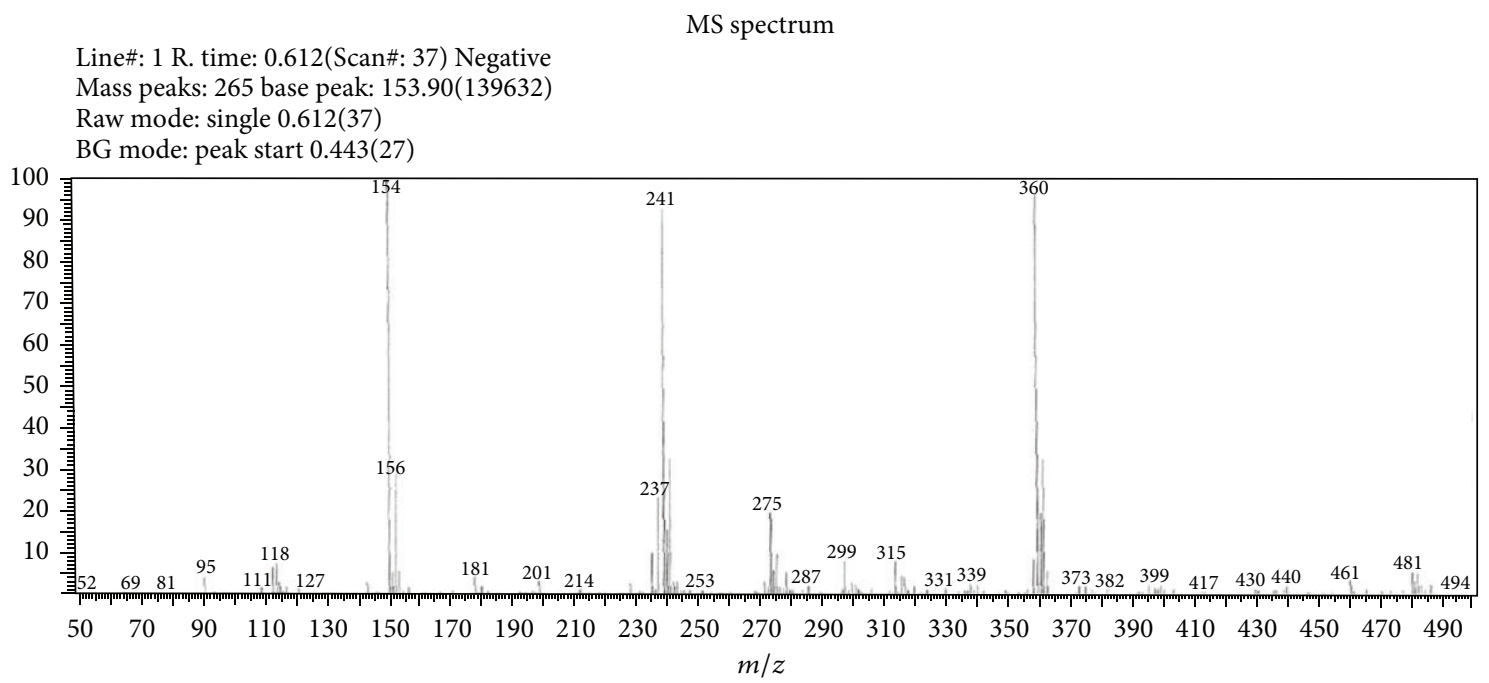

Figure 2: Mass spectrum of ligand HL.

$25635 \mathrm{~cm}^{-1}$, which corresponds to $v_{1}, v_{2}$, and $v_{3}$. This may be assigned to ${ }^{6} \mathrm{~A}_{1 \mathrm{~g}} \longrightarrow{ }^{4} \mathrm{~T}_{1 \mathrm{~g}},{ }^{6} \mathrm{~A}_{1 \mathrm{~g}} \longrightarrow{ }^{4} \mathrm{~T}_{2 \mathrm{~g}}$, and ${ }^{6} \mathrm{~A}_{1 \mathrm{~g}} \longrightarrow{ }^{4} \mathrm{~T}_{1 \mathrm{~g}},{ }^{4} \mathrm{E}_{\mathrm{g}}$ transitions, respectively, typical of an octahedral geometry. These observed values for $\mathrm{Fe}(\mathrm{III})$ complex in its visible spectrum are in agreement with the literature values [33] and thereby proved to have octahedral geometry for the $\mathrm{Fe}(\mathrm{III})$ complex of the ligand HL.

3.6. Magnetic Susceptibility Data. Magnetic susceptibility measurements of the complexes were performed at room temperature. The magnetic moment for $\mathrm{Cu}$ (II) complex of the ligand HL is 1.91 BM. The reported value for the mononuclear $\mathrm{Cu}$ (II) having no major spin interaction is 1.75-2.20 BM [34, 35]. Thus the present $\mathrm{Cu}$ (II) complex is devoid of any spin interaction with distorted octahedral geometry. In octahedral Co(II) complex, the ground state is ${ }^{4} \mathrm{~T}_{1 \mathrm{~g}}$ and a large orbital contribution to the singlet state lowers the magnetic moment values for the various $\mathrm{Co}$ (II) complexes which is in the range 4.70-5.20 BM. In the present investigation the observed magnetic moment value for $\mathrm{Co}$ (II) complex is 5.01 BM which indicates octahedral geometry for the $\mathrm{Co}$ (II) complex. For 
<smiles>C[C]I=Cc1ccccc1O</smiles>

M 360, $362(96 \%, 33 \%)$<smiles></smiles>

$\mathrm{m} / z 241,243(92 \%, 32 \%)$<smiles></smiles>

$m / z 154,156(100 \%, 31 \%)$<smiles>COc1ccc2c(c1)[CH]2</smiles>

Scheme 2: Mass fragmention pattern of ligand HL.

$\mathrm{Ni}(\mathrm{II})$ complex the observed magnetic moment value is $2.90 \mathrm{BM}$ which is well within the expected range for $\mathrm{Ni}(\mathrm{II})$ complex with octahedral stereochemistry 2.83-4.00 BM [36, 37]. For $\mathrm{Mn}$ (II) and $\mathrm{Fe}$ (III) complexes the observed magnetic moment value is $5.68 \mathrm{BM}$ and $5.91 \mathrm{BM}$, respectively, which are characteristic of octahedral geometry (Table 1).

3.7. ESR Spectral Studies of the Cu(II) Complex of the Ligand HL. The X-Band ESR spectrum of the powder $\mathrm{Cu}(\mathrm{II})$ complex was recorded at room temperature using DPPH as reference standard. One unpaired electron in $\mathrm{Cu}$ (II) complex with ${ }^{2} \mathrm{~B}_{1 \mathrm{~g}}$ as ground state lies in $\mathrm{d} x^{2}-y^{2}$ orbital and follows the trend $g_{\|}>g_{\perp}>g_{e}\left(g_{e}=2.0036\right.$ free ion value $)$.

The observed $g_{\|}=2.36, g_{\perp}=2.07$ values of the $\mathrm{Cu}$ (II) complex under the present study followed the same trend $g_{\|}>g_{\perp}>g_{e}$ which suggest the presence of unpaired electron in $\mathrm{d} x^{2}-y^{2}$ orbital giving octahedral geometry [35].
The observed $G=5.14$ for the complexes under present study evidenced the monomeric nature of the complexes; this fact is further supported by the absence of a band corresponding to $\Delta \mathrm{MS}= \pm 2$ transition in the observed ESR spectrum which is characteristic of monomeric complex (Table 3 ).

Consider

$$
G=\frac{\left(G_{\|}-2\right)}{\left(G_{\perp}-2\right)}=5.14
$$

3.8. Thermogravimetric Analysis. Thermogravimetry (TG) is a technique in which the change in mass of the sample is determined as a function of temperature and/or time. Among all the methods, TG is the most widely used one. From TG curve, information related to the thermal stabilities, composition of the initial sample, intermediate compounds that are formed, and the final residue could be obtained (Figure 3).

The TGA study on $\left[\mathrm{Cu}(\mathrm{HL})_{2}\right]$ and $\left[\mathrm{Co}(\mathrm{HL})_{2}\right]$ was carried out in the temperature range $38.69^{\circ} \mathrm{C}$ to $800^{\circ} \mathrm{C}$.

3.8.1. $\mathrm{Cu}(\mathrm{II})$ Complex. The decomposition studies of the compound $\mathrm{Cu}(\mathrm{II})$ complex $\left[\mathrm{Cu}(\mathrm{HL})_{2}\right]$ have been carried out. In the thermogram of the $\left[\mathrm{Cu}(\mathrm{HL})_{2}\right]$, (Figure 4$)$ the first stage of the decomposition represents the weight loss of $\mathrm{N}_{2} \mathrm{H}_{2}$ at $97.52^{\circ} \mathrm{C}$, with weight loss of $4.14 \%$. The theoretical weight loss for this decomposition was 3.83\% agreeing with observed value of $4.14 \%$. The complex underwent further degradation and gave break at $218.27^{\circ} \mathrm{C}$ with a weight loss of $26.22 \%$, which corresponds to the simultaneous decomposition of the $\mathrm{C}_{9} \mathrm{H}_{6} \mathrm{OSCl}$ and $\mathrm{H}_{2}$ species. This practical weight loss $26.22 \%$ is in accordance with theoretical weight loss of $25.47 \%$. The third stage of decomposition occurs at $290.97^{\circ} \mathrm{C}$, with weight loss of $25.53 \%$ which corresponds to the decomposition of $\mathrm{C}_{9} \mathrm{H}_{6} \mathrm{OSCl}$ species. This practical weight loss $25.53 \%$ is in accordance with theoretical weight loss of $25.80 \%$. The fourth stage degradation at $328^{\circ} \mathrm{C}$ with weight loss of $16.73 \%$ corresponds to the decomposition of $\mathrm{C}_{7} \mathrm{H}_{6} \mathrm{~N}_{2} \mathrm{O}$ species. This practical weight loss $16.73 \%$ is in accordance with theoretical weight loss $16.84 \%$. Thereafter compound showed a gradual decomposition up to $800^{\circ} \mathrm{C}$ and onwards. The weight of the residue corresponds to copper oxide. The thermal decomposition of $\left[\mathrm{Cu}(\mathrm{HL})_{2}\right]$ with probable assignments is given in Table 4.

3.8.2. Co(II) Complex. In the thermogram of the $\left[\mathrm{Co}(\mathrm{HL})_{2}\right]$, (Figure 5) the loss of $\mathrm{C}_{26} \mathrm{H}_{18} \mathrm{~N}_{2} \mathrm{O}_{4} \mathrm{~S}_{2} \mathrm{Cl}_{2}$ was observed at $231.81^{\circ} \mathrm{C}$, with weight loss of $71.67 \%$. This practical weight loss $71.67 \%$ is in accordance with the theoretical weight loss $71.50 \%$. The resultant intermediate complex underwent further degradation and gave another break at $392.99^{\circ} \mathrm{C}$ with a weight loss of $12.53 \%$, which corresponds to the simultaneous decomposition of the $\mathrm{C}_{6} \mathrm{H}_{6} \mathrm{O}$ and $\mathrm{H}_{2}$ species from the above intermediate complexes. The theoretical weight loss for this decomposition corresponds to $12.07 \%$ agreeing well with the observed value $12.53 \%$. Thereafter compound showed a gradual decomposition up to $800^{\circ} \mathrm{C}$ and onwards. The weight residue corresponds to cobalt oxide $\left(\mathrm{Co}_{3} \mathrm{O}_{4}\right)$. The thermal 


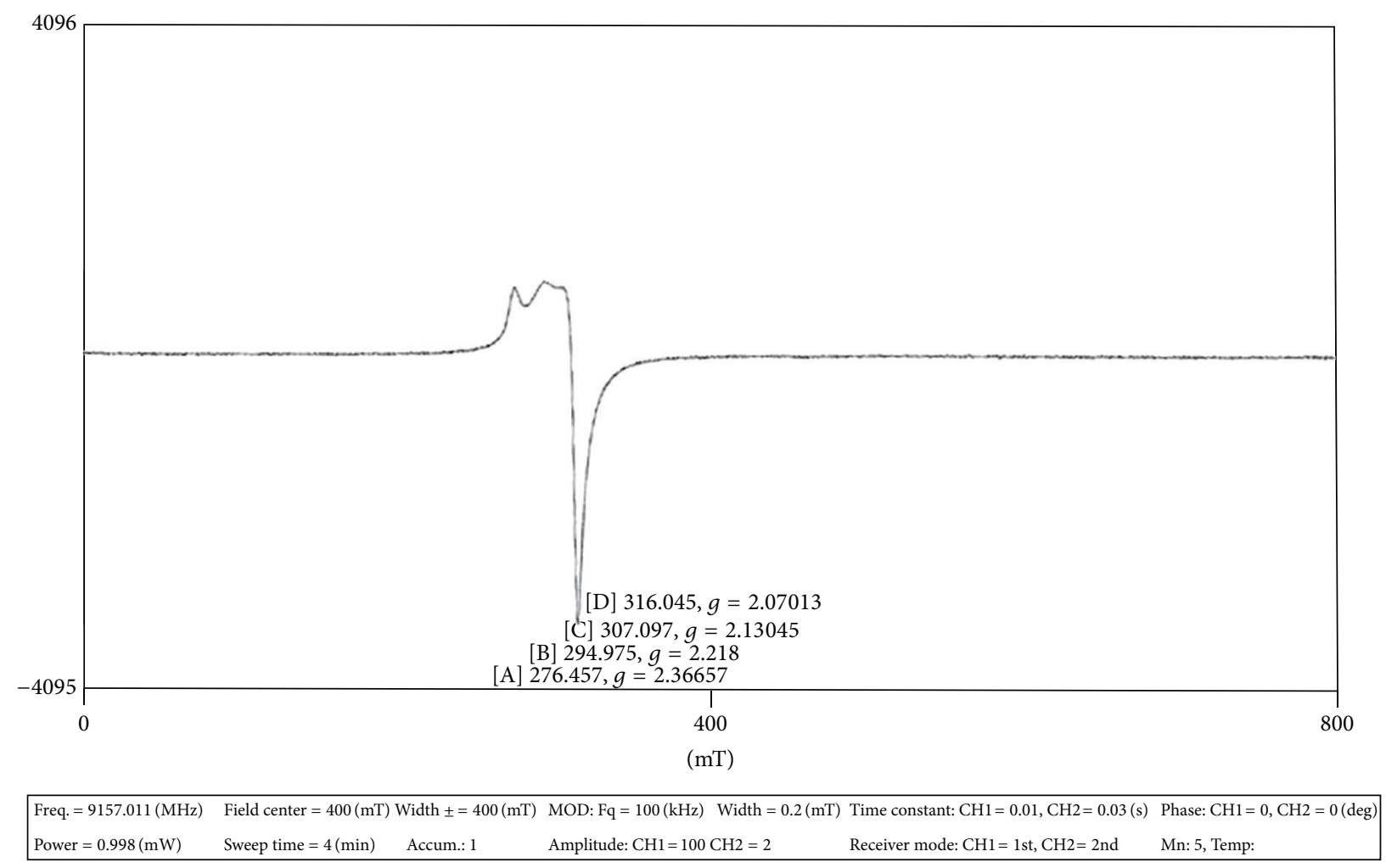

FIgURE 3: ESR spectrum of $\mathrm{Cu}(\mathrm{II})$ complex.

TABLE 4: Thermal decomposition of $\mathrm{Cu}(\mathrm{II})$ complex of ligand HL.

\begin{tabular}{|c|c|c|c|c|c|}
\hline \multirow{2}{*}{ Complex } & \multirow{2}{*}{ Stage } & \multirow{2}{*}{$\begin{array}{l}\text { Peak temp TG } \\
\left({ }^{\circ} \mathrm{C}\right)\end{array}$} & \multicolumn{2}{|c|}{ Loss of mass (\%) } & \multirow{2}{*}{ Probable assignments } \\
\hline & & & Practical & Theoretical & \\
\hline \multirow{8}{*}[\mathrm{C}(\mathrm{HL})_{2}]{} & - & - & - & - & $\mathrm{C}_{34} \mathrm{H}_{24} \mathrm{~N}_{4} \mathrm{O}_{6} \mathrm{~S}_{2} \mathrm{Cl}_{2} \mathrm{Cu}$ \\
\hline & & & & & $-\mathrm{N}_{2} \mathrm{H}_{2}$ \\
\hline & I & 97.52 & 4.14 & 3.83 & $\mathrm{C}_{34} \mathrm{H}_{22} \mathrm{~N}_{2} \mathrm{O}_{6} \mathrm{~S}_{2} \mathrm{Cl}_{2} \mathrm{Cu}$ \\
\hline & & & & & $\downarrow \begin{array}{l}-\mathrm{C}_{9} \mathrm{H}_{6} \mathrm{OSCl} \\
-\mathrm{H}_{2}\end{array}$ \\
\hline & II & 218.27 & 26.22 & 25.47 & $\begin{array}{r}\mathrm{C}_{25} \mathrm{H}_{14} \mathrm{~N}_{2} \mathrm{O}_{5} \mathrm{SClCu}_{5} \\
\mid-\mathrm{C}_{9} \mathrm{H}_{6} \mathrm{OSCl}\end{array}$ \\
\hline & III & 290.97 & 25.53 & 25.80 & $\mathrm{C}_{16} \mathrm{H}_{8} \mathrm{~N}_{2} \mathrm{O}_{4} \mathrm{Cu}$ \\
\hline & & & & & $\downarrow-\mathrm{C}_{7} \mathrm{H}_{6} \mathrm{~N}_{2} \mathrm{O}$ \\
\hline & IV & 328 & 16.73 & 16.84 & $\mathrm{C}_{9} \mathrm{H}_{2} \mathrm{O}_{3} \mathrm{Cu}$ \\
\hline
\end{tabular}

decomposition of $\left[\mathrm{Co}(\mathrm{HL})_{2}\right]$ with probable assignments is given in Table 5.

\subsection{Powder X-Ray Diffraction}

3.9.1. Cu(II) Complex. Powder X-ray diffraction pattern for $\mathrm{Cu}(\mathrm{II})$ complex of ligand HL has been depicted in Figure 6.
The Copper complex of $\left[\mathrm{Cu}(\mathrm{HL})_{2}\right]$ showed nine reflections in the range of $5-80^{\circ}(2 \theta)$ arising from diffraction of X-ray by planes of complex. The interplanar spacing $(d)$ has been calculated from the position of intense peak using Bragg's equation

$$
\eta \lambda=2 d \sin \theta,
$$

where $\lambda=$ wavelength of X-ray used ( $\mathrm{Cu} \mathrm{K} \alpha=1.54 \AA)$. 
TABle 5: Thermal decomposition of Co(II) complex of ligand HL.

\begin{tabular}{|c|c|c|c|c|c|}
\hline \multirow{2}{*}{ Complex } & \multirow{2}{*}{ Stage } & \multirow{2}{*}{$\begin{array}{c}\text { Peak temp TG } \\
\left({ }^{\circ} \mathrm{C}\right)\end{array}$} & \multicolumn{2}{|c|}{ Loss of mass (\%) } & \multirow{2}{*}{ Probable assignments } \\
\hline & & & Practical & Theoretical & \\
\hline \multirow[t]{4}{*}[\mathrm{C}(\mathrm{HL})_{2}]{} & - & - & - & - & $\mathrm{C}_{34} \mathrm{H}_{24} \mathrm{~N}_{4} \mathrm{O}_{6} \mathrm{~S}_{2} \mathrm{Cl}_{2} \mathrm{Cu}$ \\
\hline & & & & & $\downarrow-\mathrm{C}_{26} \mathrm{H}_{18} \mathrm{O}_{4} \mathrm{Cl}_{2} \mathrm{~N}_{2} \mathrm{~S}_{2}$ \\
\hline & I & 231.81 & 71.67 & 71.50 & $\begin{array}{c}\mathrm{C}_{8} \mathrm{H}_{6} \mathrm{~N}_{2} \mathrm{O}_{2} \mathrm{Co} \\
\downarrow \\
\downarrow-\mathrm{C}_{6} \mathrm{H}_{4} \mathrm{O} \\
-\mathrm{H}_{2}\end{array}$ \\
\hline & II & 392.99 & 12.53 & 12.07 & $\mathrm{C}_{2} \mathrm{~N}_{2} \mathrm{OCo}$ \\
\hline
\end{tabular}

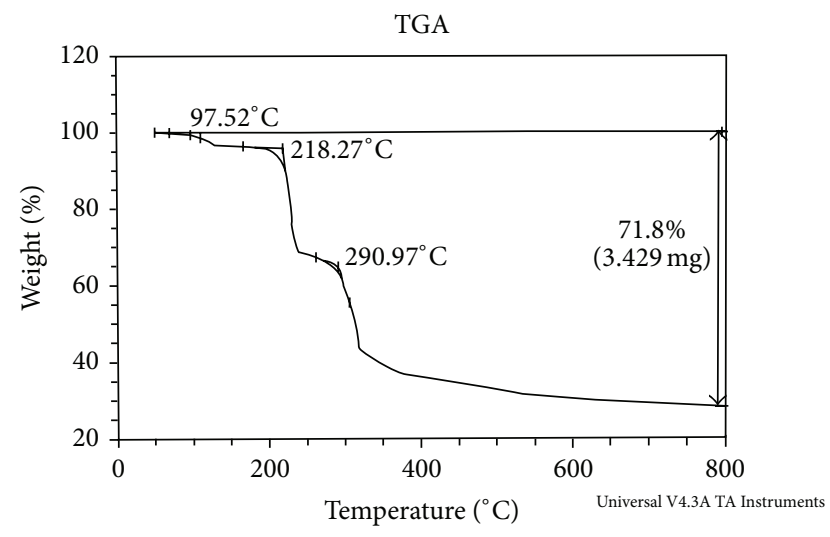

FIgURE 4: Thermogram of $\mathrm{Cu}(\mathrm{II})$ complex.

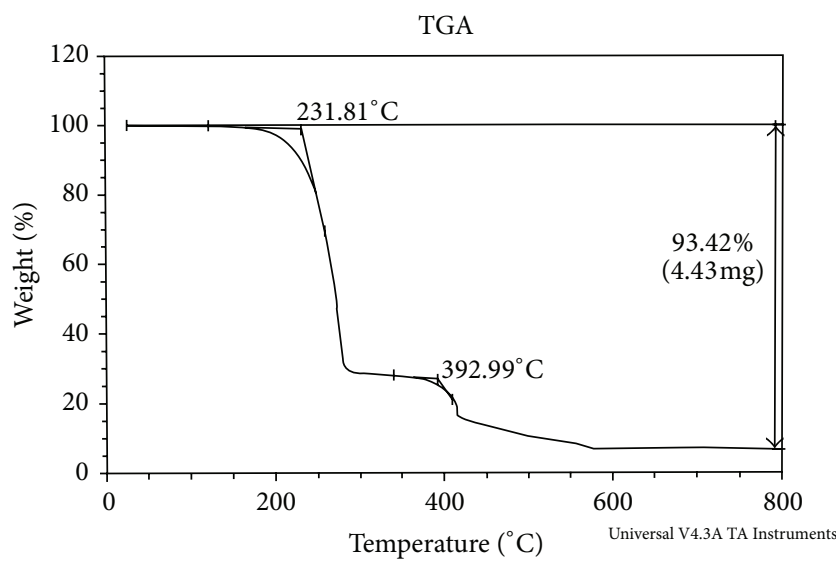

FIgURE 5: Thermogram of Co(II) complex.

The calculated spacing together with relative intensities with respect to most intense peak has been recorded in Table 6.

The $2 \theta$ value with maximum intensity of the peak for the compound was found to be $25.457(2 \theta)$ which corresponds to $d=3.49612 \AA$. The $2 \theta$ values for the prominent peaks have

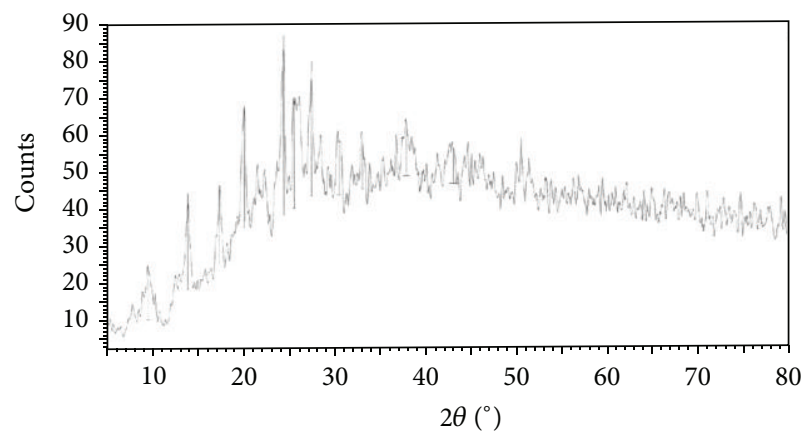

Central Instruments Laboratory, University of Hyderabad

FIgure 6: Powder X-ray diffraction of $\mathrm{Cu}(\mathrm{II})$ complex.

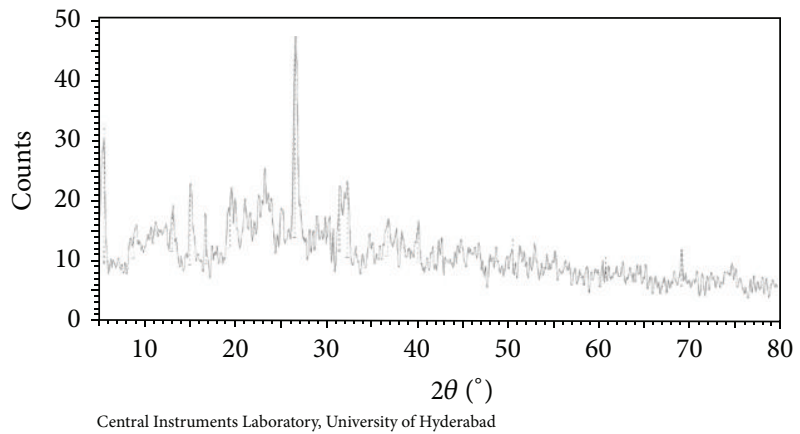

Figure 7: Powder X-ray diffraction of Co(II) complex.

been listed in Table 6 . The entire important peaks have been indexed and unit cell calculations have been made for cubic symmetry of the complex. The observed values of interplanar distance have been compared with the calculated ones. It was observed that there is good agreement between the calculated and observed values. The experimental values of $\sin ^{2} \theta$ /common factor are recorded for each peak in Figure 6. The $\left(h^{2}+k^{2}+l^{2}\right)$ values are $1,2,3,4,7,10,12,15$, and 20. The presence of forbidden no 7 and 15 indicates that the $\mathrm{Cu}(\mathrm{II})$ complex may belong to hexagonal or tetragonal system. 
TABle 6: Powder X-ray diffraction data of $\mathrm{Cu}(\mathrm{II})$ of the ligand HL.

\begin{tabular}{lccccccccc}
\hline Peak & $2 \theta$ & $\theta$ & $\sin \theta$ & $\sin ^{2} \theta$ & $h k l$ & Calc. & Obser. & $h^{2}+k^{2}+l^{2}$ & $a$ in $\AA$ \\
\hline 1 & 9.484 & 4.742 & 0.0826 & 0.00682 & 100 & 9.32567 & 9.32567 & 1 \\
2 & 13.899 & 6.9495 & 0.12099 & 0.01464 & 110 & 6.36664 & 6.36664 & 2 \\
3 & 17.399 & 8.6995 & 0.15125 & 0.02288 & 111 & 5.09289 & 5.09289 & 3 \\
4 & 20.154 & 10.077 & 0.17497 & 0.03061 & 200 & 4.40247 & 4.40247 & 4 \\
5 & 25.457 & 12.7285 & 0.22033 & 0.04855 & - & 3.49612 & 3.49612 & 7 \\
6 & 30.446 & 15.233 & 0.26257 & 0.06894 & 310 & 2.93369 & 2.93369 & 9.3277 \\
7 & 33.056 & 16.528 & 0.28448 & 0.08093 & 222 & 2.70775 & 2.70775 & 9.3277 \\
8 & 37.844 & 18.922 & 0.32428 & 0.10516 & - & 2.37542 & 2.37542 & 12 & 9.3277 \\
9 & 42.952 & 21.476 & 0.36611 & 0.13404 & 420 & 2.10401 & 2.10401 & 9.3277 \\
\hline
\end{tabular}

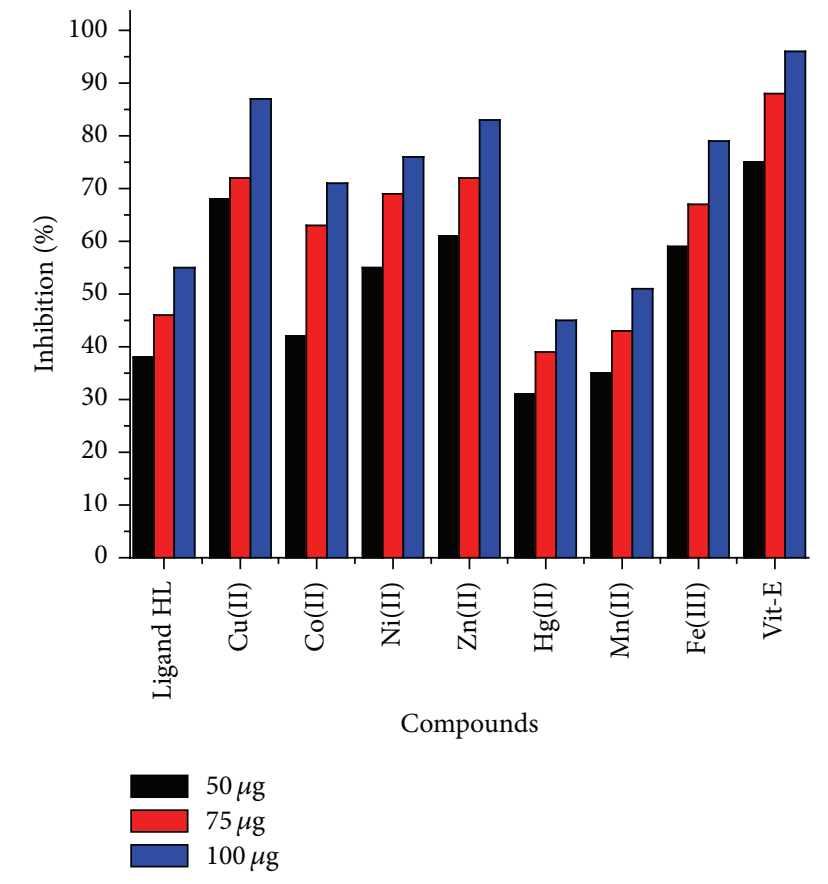

Figure 8: Antioxidant activities of ligand HL and its complexes.<smiles>COc1ccc2c(Cl)c(C(=O)N/N=C/c3ccccc3O)sc2c1</smiles>

Figure 9: Schiff base HL.

3.9.2. Co(II) Complex. Powder X-ray diffraction pattern for $\mathrm{Co}(\mathrm{II})$ complex of ligand HL has been depicted in Figure 7. The copper complex of $\left[\mathrm{Co}(\mathrm{HL})_{2}\right]$ showed eleven reflections in the range of $5-80^{\circ}(2 \theta)$ arising from diffraction of X-ray by planes of complex. The interplanar spacing $(d)$ has been calculated from the position of intense peak using Bragg's equation

$$
\eta \lambda=2 d \sin \theta
$$

The calculated spacing together with relative intensities with respect to most intense peak has been recorded in Table 7.

The $2 \theta$ value with maximum intensity of the peak for the compound was found to be $26.5511(2 \theta)$ which corresponds to $d=3.35453 \AA$. The $2 \theta$ values for the prominent peaks have been listed in Table 7. The entire important peaks have been indexed and unit cell calculations have been made for cubic symmetry of the complex. The observed values of interplanar distance have been compared with the calculated ones. It was observed that there is good agreement between the calculated and observed values. The experimental values of $\sin ^{2} \theta /$ common factor are recorded for each peak in Figure 7 . The $\left(h^{2}+k^{2}+l^{2}\right)$ are $1,2,3,5,9,12,17,20,30,43$, and 54 . The absence of forbidden no 7, 15, and 23 conforms the cubic symmetry. The experimental values are in good agreement with $\left(h^{2}+k^{2}+l^{2}\right)$ values of primitive type cubic cell, with lattice parameter equal to $a=b=c=9.9518$.

3.10. Antimicrobial Activity. Antimicrobial activity was carried out by the cup-plate method [33]. The ligand HL and its $\mathrm{Cu}(\mathrm{II}), \mathrm{Co}(\mathrm{II}), \mathrm{Ni}(\mathrm{II}), \mathrm{Zn}(\mathrm{II}), \mathrm{Hg}(\mathrm{II}), \mathrm{Mn}(\mathrm{II})$, and $\mathrm{Fe}$ (III) complexes have been tested for their antibacterial and antifungal activity at $1 \mathrm{mg} / \mathrm{mL}$ concentration. The results of the antimicrobial activity have been presented in Table 8 . The results of the antibacterial activity testing showed that the complexes of $\mathrm{Hg}$ (II) and $\mathrm{Mn}$ (II) showed good activity, complexes of $\mathrm{Cu}(\mathrm{II}), \mathrm{Co}(\mathrm{II}), \mathrm{Ni}(\mathrm{II})$, and $\mathrm{Fe}(\mathrm{III})$ exhibited moderate activity, and ligand HLand complex of $\mathrm{Zn}$ (II) showed less activity against $E$. coli when compared with that of standard drug Streptomycin. The complexes of $\mathrm{Hg}$ (II) and $\mathrm{Mn}$ (II) showed good activity, and complexes of $\mathrm{Cu}(\mathrm{II}), \mathrm{Co}(\mathrm{II}), \mathrm{Ni}(\mathrm{II})$, and $\mathrm{Fe}(\mathrm{III})$ exhibited moderate activity against $S$. aureus when compared with that of standard drug Streptomycin.

The results of the antifungal activity testing of the ligand $\mathrm{HL}$ and its $\mathrm{Cu}(\mathrm{II}), \mathrm{Co}(\mathrm{II}), \mathrm{Ni}(\mathrm{II}), \mathrm{Zn}(\mathrm{II}), \mathrm{Hg}(\mathrm{II}), \mathrm{Mn}(\mathrm{II})$, and 


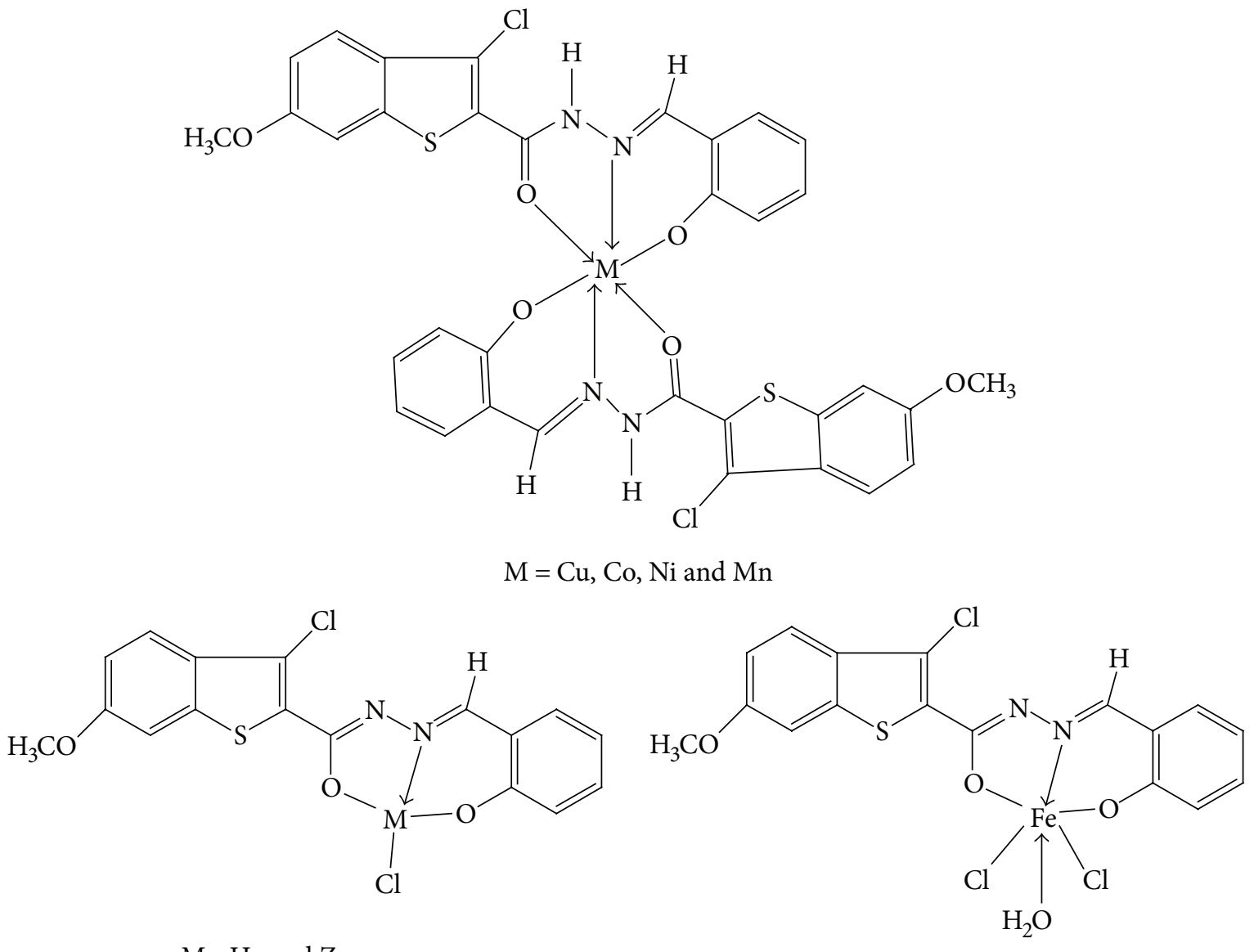

$\mathrm{M}=\mathrm{Hg}$ and $\mathrm{Zn}$

FIGURE 10: Proposed structure of the complexes of ligand HL.

TABle 7: Powder X-ray diffraction data of Co(II) complex of the ligand HL.

\begin{tabular}{|c|c|c|c|c|c|c|c|c|c|}
\hline Peak & $2 \theta$ & $\theta$ & $\sin \theta$ & $\sin ^{2} \theta$ & $h k l$ & Calc. & Obser. & $h^{2}+k^{2}+l^{2}$ & $a$ in $\AA$ \\
\hline 1 & 8.8805 & 4.44025 & 0.07742 & 0.00599 & 100 & 9.94963 & 9.94939 & 1 & 9.9518 \\
\hline 2 & 13.0916 & 6.5458 & 0.1139 & 0.01299 & 110 & 6.75761 & 6.75698 & 2 & 9.9518 \\
\hline 3 & 15.0632 & 7.5316 & 0.1310 & 0.01718 & 111 & 5.87701 & 5.87671 & 3 & 9.9518 \\
\hline 4 & 19.5309 & 9.7654 & 0.1696 & 0.02877 & 210 & 4.54133 & 4.54133 & 5 & 9.9518 \\
\hline 5 & 26.5511 & 13.2755 & 0.2296 & 0.05273 & 300 & 3.35453 & 3.35438 & 9 & 9.9518 \\
\hline 6 & 30.7545 & 15.3772 & 0.2651 & 0.07032 & 222 & 2.90493 & 2.90481 & 12 & 9.9518 \\
\hline 7 & 36.8253 & 18.4126 & 0.3158 & 0.09977 & 410 & 2.43874 & 2.43869 & 17 & 9.9518 \\
\hline 8 & 40.0795 & 20.0397 & 0.3426 & 0.11742 & 420 & 2.24794 & 2.24787 & 20 & 9.9518 \\
\hline 9 & 50.5420 & 25.2710 & 0.4269 & 0.18224 & 521 & 1.8044 & 1.80436 & 30 & 9.9518 \\
\hline 10 & 60.7614 & 30.3807 & 0.5057 & 0.25577 & 533 & 1.52311 & 1.52306 & 43 & 9.9518 \\
\hline 11 & 69.1800 & 34.5900 & 0.5677 & 0.32228 & 721 & 1.35688 & 1.35684 & 54 & 9.9518 \\
\hline
\end{tabular}

$\mathrm{Fe}(\mathrm{III})$ complexes showed that the complex of $\mathrm{Hg}$ (II) showed good activity and complexes of $\mathrm{Co}(\mathrm{II}), \mathrm{Ni}(\mathrm{II})$, and $\mathrm{Mn}$ (II) exhibited moderate activity against $A$. niger when compared with standard drug Fluconazole at the same concentration as that of the test compound. Ligand HL and complexes of $\mathrm{Cu}(\mathrm{II}), \mathrm{Zn}(\mathrm{II})$, and Fe(III) showed less activity. The complex of $\mathrm{Hg}$ (II) showed good activity, complexes of $\mathrm{Ni}$ (II), $\mathrm{Zn}$ (II), and $\mathrm{Mn}(\mathrm{II})$ exhibited moderate activity, and ligand $\mathrm{HL}$ and complexes of $\mathrm{Cu}(\mathrm{II}), \mathrm{Co}(\mathrm{II})$, and $\mathrm{Fe}(\mathrm{III})$ showed less activity against $A$. flavus when compared with standard drug Fluconazole.

3.11. Antioxidant Activity by DPPH Radical Scavenging Activity. DPPH scavenging activity of ligand and its complexes against vitamin-E as standard were analyzed at $50-100 \mu \mathrm{g}$ in DMF solution at $T=30 \mathrm{~min}$. This investigation 
TABLE 8: Antimicrobial activity screening data of the ligand HL and its complexes.

\begin{tabular}{|c|c|c|c|c|}
\hline \multirow{3}{*}{ Ligand/complexes } & \multicolumn{4}{|c|}{ Antimicrobial activity (zone of inhibition in $\mathrm{mm})^{*}$} \\
\hline & \multicolumn{2}{|c|}{ Antibacterial activity } & \multicolumn{2}{|c|}{ Antifungal activity } \\
\hline & E. coli & S. aureus & A. niger & A. flavus \\
\hline HL & 12 & 13 & 11 & 10 \\
\hline $\mathrm{Cu}$-complex & 16 & 16 & 11 & 13 \\
\hline Co-complex & 17 & 16 & 14 & 12 \\
\hline Ni-complex & 17 & 17 & 15 & 14 \\
\hline Zn-complex & 14 & 15 & 12 & 14 \\
\hline Hg-complex & 21 & 20 & 18 & 17 \\
\hline Mn-complex & 18 & 18 & 14 & 15 \\
\hline Fe-complex & 17 & 16 & 12 & 11 \\
\hline Streptomycin & 22 & 21 & - & - \\
\hline Fluconazole & - & - & 19 & 20 \\
\hline DMF (control) & 0 & 0 & 0 & 0 \\
\hline
\end{tabular}

${ }^{*}$ Bore size- $6 \mathrm{~mm}$.

indicates that there is a great possibility of finding potent antioxidants. The $\mathrm{Cu}(\mathrm{II}), \mathrm{Ni}(\mathrm{II}) \mathrm{Zn}(\mathrm{II})$, and Fe(III) complexes have exhibited very good free radical scavenging activity, and $\mathrm{Co}$ (II) showed moderate activity. Ligand $\mathrm{HL}$ and its $\mathrm{Hg}$ (II) and $\mathrm{Mn}$ (II) complexes showed less activity compared with Vit-E. The bar graph representation of percentage of free radical scavenging activities is shown in Figure 8.

\section{Conclusion}

In the light of above discussion we have proposed that $\mathrm{Cu}(\mathrm{II})$, $\mathrm{Co}(\mathrm{II}), \mathrm{Ni}(\mathrm{II}), \mathrm{Mn}(\mathrm{II})$, and Fe(III) complexes have exhibited octahedral geometry whereas $\mathrm{Zn}$ (II) and $\mathrm{Hg}$ (II) complexes exhibited tetrahedral geometry. The ligand behaves as ONO tridentate chelating agent coordinating through the deprotonation of hydroxyl group, carbonyl group, and azomethine nitrogen. The elemental analysis, electrical conductivity measurements, IR spectra, ${ }^{1} \mathrm{H}$ NMR, mass spectral data, electronic spectra, magnetic susceptibility, ESR spectra, and TGA revealed mononuclear nature of the complexes. The ligand HL was found to be less active against the bacteria as well as fungi whereas its complexes were found to be highly active against the bacteria as well as fungi and some of the complexes showed good antioxidant activity. On the basis of spectral evidence following structures have been assigned for synthesized complexes.

\section{Acknowledgments}

The authors are grateful to Chairman, Department of Chemistry, Gulbarga, University, Gulbarga, for providing the laboratory facilities. They also thank the directors of IISc, Bangalore, STIC, Kochi, and CDRI, Lucknow, for ${ }^{1} \mathrm{H}$ NMR, ESR, FAB-Mass, TGA, and elemental data.

\section{References}

[1] U. G. Deshpande and J. R. Shah, "Coordination Polymers. IV. physicochemical studies on chelate polymers of $\mathrm{Cr}(\mathrm{III}), \mathrm{Mn}(\mathrm{II})$,
$\mathrm{Fe}(\mathrm{II}), \mathrm{Co}(\mathrm{II}), \mathrm{Ni}(\mathrm{II})$, and $\mathrm{Cu}(\mathrm{II})$ with a schiff base of $4,4^{\prime}-\left(4,4^{\prime}\right.$ Biphenylylene Bisazo)di-(salicylaldehyde) with m-Toluidine," Journal of Macromolecular Science: Part A, vol. 20, no. 3, pp. 355-363, 1983.

[2] F. A. Cotton, Progress in Inorganic Chemistry, vol. 7, Wiley, New York, USA, 1966.

[3] H. Torayama, T. Nishide, H. Asada, M. Fujiwara, and T. Matsushita, "Preparation and characterization of novel cyclic tetranuclear manganese (III) complexes: $\mathrm{Mn}_{4}^{\mathrm{III}}$ (X-salmphen) (X-salmphen $\mathrm{H}_{2}=N, N^{\prime}$-di-substituted-salicylidene-1,3-diaminobenzene $(\mathrm{X}=\mathrm{H}, 5-\mathrm{Br})$ ), Polyhedron, vol. 16, no. 21, pp. 37873794, 1997.

[4] T. Punniyamurthy, S. J. S. Kalra, and J. Iqbal, "Cobalt(II) catalyzed biomimetic oxidation of hydrocarbons in the presence of dioxygen and 2-methylpropanal," Tetrahedron Letters, vol. 36, no. 46, pp. 8497-8500, 1995.

[5] S. S. Chavan and P. P. Hankare, "X-ray diffraction studies of $\mathrm{Ni}(\mathrm{II}), \mathrm{Cu}(\mathrm{II})$ and $\mathrm{Zn}$ (II) complexes with 2-[2'-hydroxysalicylidene- $5^{\prime}-\left(2^{\prime \prime}\right.$-thiazolylazo $\left.)\right]$ phenol," Journal of the Indian Chemical Society, vol. 82, no. 6, pp. 494-496, 2005.

[6] Z. H. Chohan, M. Praveen, and A. Ghaffar, "Synthesis, characterisation and biological role of anions (Nitrate, Sulphate, Oxalate and Acetate) in $\mathrm{Co}(\mathrm{II}), \mathrm{Cu}(\mathrm{II})$ and $\mathrm{Ni}(\mathrm{II})$ metal chelates of some Schiff base derived Amino Acids," Synthesis and Reactivity in Inorganic and Metal-Organic Chemistry, vol. 28, no. 10, pp. 1673-1687, 1998.

[7] B.-L. Chen, K.-F. Mok, S.-C. Ng, and M. G. B. Drew, "Syntheses, structures and properties of copper(II) complexes with thiophene-2,5-dicarboxylic acid $\left(\mathrm{H}_{2} \mathrm{Tda}\right)$ and nitrogencontaining ligands," Polyhedron, vol. 18, no. 8-9, pp. 1211-1220, 1999.

[8] E. Abele and E. Lukevics, "Synthesis of sterically hindered heteroaromatic ketones under phase-transfer and metal-complex catalysis conditions," Chemistry of Heterocyclic Compounds, vol. 37, no. 1, pp. 5-14, 2001.

[9] T. A. Farghaly and Z. A. Abdallah, "Synthesis, azo-hydrazone tautomerism and antitumor screening of $\mathrm{N}$-(3-ethoxycarbonyl4,5,6,7-tetrahydro-benzo[b]thien-2-yl)-2-arylhydrazono-3oxobutanamide derivatives," Arkivoc, vol. 2008, no. 17, pp. 295-305, 2008. 
[10] S. L. Vasoya, D. J. Paghdar, P. T. Chovatia, and H. S. Joshi, "Synthesis of some new thiosemicarbazide and 1, 3, 4-thiadiazole hetrocycles bearing benzo[b]thiophene nucleus as a potent antitubercular and antimicrobial agents," Journal of Sciences Islamic Republic of Iran, vol. 16, no. 1, pp. 33-36, 2005.

[11] Y. Jadegoud, O. B. Ijare, N. N. Mallikarjuna, S. D. Angadi, and B. H. M. Mruthyunjayaswamy, "Synthesis and antimicrobial activity of copper, cobalt and nickel(II) complexes with Schiff bases," Journal of the Indian Chemical Society, vol. 79, no. 12, pp. 921-924, 2002.

[12] B. H. M. Mruthyunjayaswamy, Y. Jadegoud, O. B. Ijare, S. G. Patil, and S. M. Kudari, "Synthesis, characterization and antimicrobial activity of macrocylic phenoxo-bridged di and tetra-nuclear complexes from $N, N$-bis[2,6-diiminomethyl-4methyl-1-hydroxyphenyl]succinoyl/sebacoyldicarboxamides," Transition Metal Chemistry, vol. 30, no. 2, pp. 234-242, 2005.

[13] B. H. M. Mruthyunjayaswamy, O. B. Ijare, and Y. Jadegoud, "Synthesis, characterization and biological activity of symmetric dinuclear complexes derived from a novel macrocyclic compartmental ligand," Journal of the Brazilian Chemical Society, vol. 16, no. 4, pp. 783-789, 2005.

[14] Y. Jadegoud, O. B. Ijare, B. S. Somashekar, G. A. N. Gowda, and B. H. M. Mruthyunjayaswamy, "Synthesis, characterization and antimicrobial activity of homodinuclear complexes derived from 2,6-bis $\left[3^{\prime}\right.$-methyl- $2^{\prime}$-carboxamidyliminomethyl $\left(6^{\prime}, 7^{\prime}\right)$ benzindole]-4-methylphenol, an end-off compartmental ligand," Journal of Coordination Chemistry, vol. 61, no. 4, pp. 508-527, 2008.

[15] F. Rahaman, B. Hiremath, S. M. Basavarajaiah, B. H. M. Jayakumarswamy, and B. H. M. Mruthyunjayaswamy, "Synthetic, spectral, thermal and antimicrobial activity studies of some transition metal complexes derived from 2-hydroxy-methylbenzaldehyde $N$ - $\left(4^{\prime}\right.$ - phenyl-1', $3^{\prime}$-thiazol-2' -yl)semicarbazone," Journal of the Indian Chemical Society, vol. 85, no. 4, pp. 381-386, 2008.

[16] F. Rahaman, O. B. Ijare, Y. Jadegoud, and B. H. M. Mruthyunjayaswamy, "Phenoxo-bridged symmetrical homobinuclear complexes derived from an "end-off” compartmental ligand, 2,6-bis $\left[5^{\prime}\right.$-chloro- $3^{\prime}$-phenyl- $1 H$-indole- $2^{\prime}$-carboxamidyliminomethyl]-4-methylphenol," Journal of Coordination Chemistry, vol. 62, no. 9, pp. 1457-1467, 2009.

[17] A. I. Vogel, A Text Book Quantitative Organic Analysised, 3rd edition, 1962.

[18] S. P. Hiremath, K. Shivaramayya, and M. G. Purohit, "Synthesis of substituted 2,5-bis(Oxadiazolyl/Thiazolidino/Pyrazolyl/ Pyrimidinediono) indoles and Oxadiazolyl/Thiadiazolyl/Triazolyl/Thiazolidinone analogs of Benzothiophene and their antibacterial activity," Indian Journal of Heterocyclic Chemistry, vol. 1, pp. 177-184, 1992.

[19] A. I. Vogel, A Text Book of Quantitative Inorganic Analysis, Longman ELBS, London, UK, 3rd edition, 1968.

[20] C. J. O'Connor, E. Sinn, E. J. Cukauskas, and B. S. Deaver Jr., "Low temperature magnetic properties and antiferromagnetic interactions of the magnetic susceptibility calibrant $\mathrm{HgCo}(\mathrm{NCS})_{4}$," Inorganica Chimica Acta, vol. 32, no. C, pp. 2932, 1979.

[21] A. L. Barry, The Antimicrobial Susceptibility Test, Principles and Practices, E.L.B.S, 4th edition, 1976.

[22] M. S. Blois, "Antioxidant determinations by the use of a stable free radical," Nature, vol. 181, no. 4617, pp. 1199-1200, 1958.

[23] P. Molyneux, "The use of the stable free radical diphenylpicrylhydrazyl (DPPH) for estimating antioxidant activity," The
Songklanakarin Journal of Science and Technology, vol. 26, pp. 211-219, 2004.

[24] G. Topçua, A. Ertas, U. Kolak, M. Öztürk, and A. Ulubelen, "Antioxidant activity tests on novel triterpenoids from Salvia macrochlamys," Arkivoc, vol. 7, pp. 195-208, 2007.

[25] J. Sambrook, E. F. Fritsch, and T. Maniatis, Molecular Cloning. A Laboratory Manual, Cold Spring Harbor Laboratory, Cold Spring Harbor, New York, NY, USA, 2nd edition, 1989.

[26] A. A. A. Abu-Hussen, "Synthesis and spectroscopic studies on ternary bis-Schiff-base complexes having oxygen and/or nitrogen donors," Journal of Coordination Chemistry, vol. 59, no. 2, pp. 157-176, 2006.

[27] N. K. Singh, S. B. Singh, A. Shrivastav, and S. M. Singh, "Spectral, magnetic and biological studies of 1,4-dibenzoyl-3thiosemicarbazide complexes with some first row transition metal ions," Journal of Chemical Sciences, vol. 113, no. 4, pp. 257273, 2001.

[28] N. K. Singh and S. B. Singh, "Synthesis, characterization and biological properties of manganese(II), cobalt(II), nickel(II), copper(II), zinc(II), chromium(III) and iron(III) complexes with a new thiosemicarbazide derivative," Indian Journal of Chemistry: Section A, vol. 40, no. 10, pp. 1070-1075, 2001.

[29] C. N. R. Rao, Chemical Applications of Infrared Spectroscopy, Academic Press, New York, NY, USA, 1963.

[30] G. M. Shashidhara and T. R. Goudar, "Synthesis of Uranium(IV) complexes of Schiff bases," Journal of the Indian Chemical Society, vol. 78, no. 7, pp. 360-361, 2001.

[31] M. K. Patel, N. H. Patel, K. N. Patel, and M. N. Patel, "Synthesis, structural characterization and biocidal studies of $\mathrm{Cu}(\mathrm{II}), \mathrm{Ni}(\mathrm{II}), \mathrm{Zn}(\mathrm{II}), \mathrm{Co}(\mathrm{II}), \mathrm{Fe}(\mathrm{II}), \mathrm{Mn}(\mathrm{II})$ and $\mathrm{Cd}(\mathrm{II})$ complexes derived from Schiff bases (ONO) and bidentate (NN) heterocycle," Journal of Indian Council of Chemists, vol. 17, no. 1, pp. 19-24, 2000.

[32] S. Chandra and K. Gupta, "Synthesis and spectral studies on chromium(III), manganese(II), iron(III), cobalt(II), nickel(II) and copper(II) complexes of fourteen-membered and sixteen membered tetradentate macrocyclic ligands," Indian Journal of Chemistry: Section A, vol. 40, no. 7, pp. 775-779, 2001.

[33] D. Nicolas, J. C. Bailar Jr., H. J. Emelens, and R. S. Nyloms, Comprehnsive Inorganic Chemistry, 5th edition, 1973.

[34] J. L. Tian, E. Q. Gao, Y. T. Li, and S. X. Liu, "Synthesis and characterization of Glyoxalic Acid Thiosemicarbazone complexes of some Bivalent metal Ions," Synthesis and Reactivity in Inorganic and Metal-Organic Chemistry, vol. 25, no. 3, pp. 417-427, 1995.

[35] L. K. Mishra, Y. Jha, B. K. Sinha, R. Kant, and R. Singh, "Studies of chelates of cobalt-, nickel-, copper-, zinc- and cadmium(II) with 4-amino-3,5-dioxo-6-methyl-2,3,4,5-tetrahydro-1,2,4-triazine," Journal of the Indian Chemical Society, vol. 76, no. 2, pp. 65-66, 1999.

[36] M. Melník, I. Potočňak, L. Macášková, D. Mikloš, and C. E. Holloway, "Spectral study of copper(II) flufenamates: crystal and molecular structure of biis(Flufenamato)di( $N, N$ diethylnicotinamide)di(Aqua)copper(II)," Polyhedron, vol. 15, no. 13 , pp. $2159-2164,1996$.

[37] B. J. Hathaway and A. A. G. Tomlinson, "Copper(II) ammonia complexes," Coordination Chemistry Reviews, vol. 5, no. 1, pp. $1-43,1970$. 

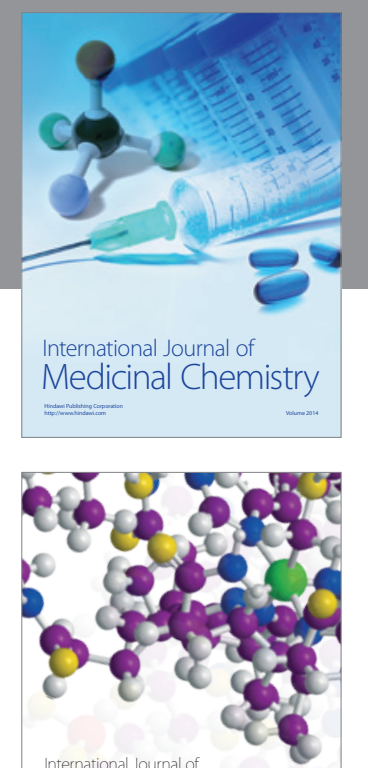

\section{Carbohydrate} Chemistry

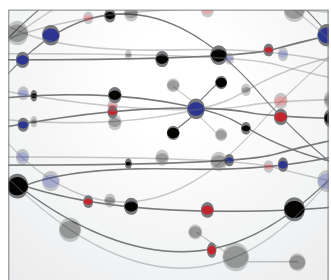

The Scientific World Journal
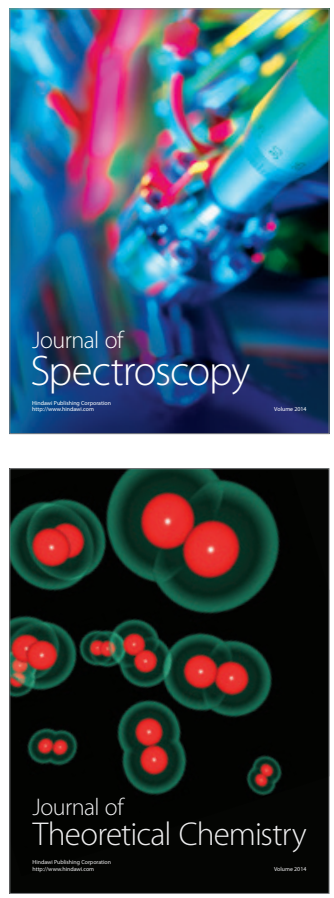
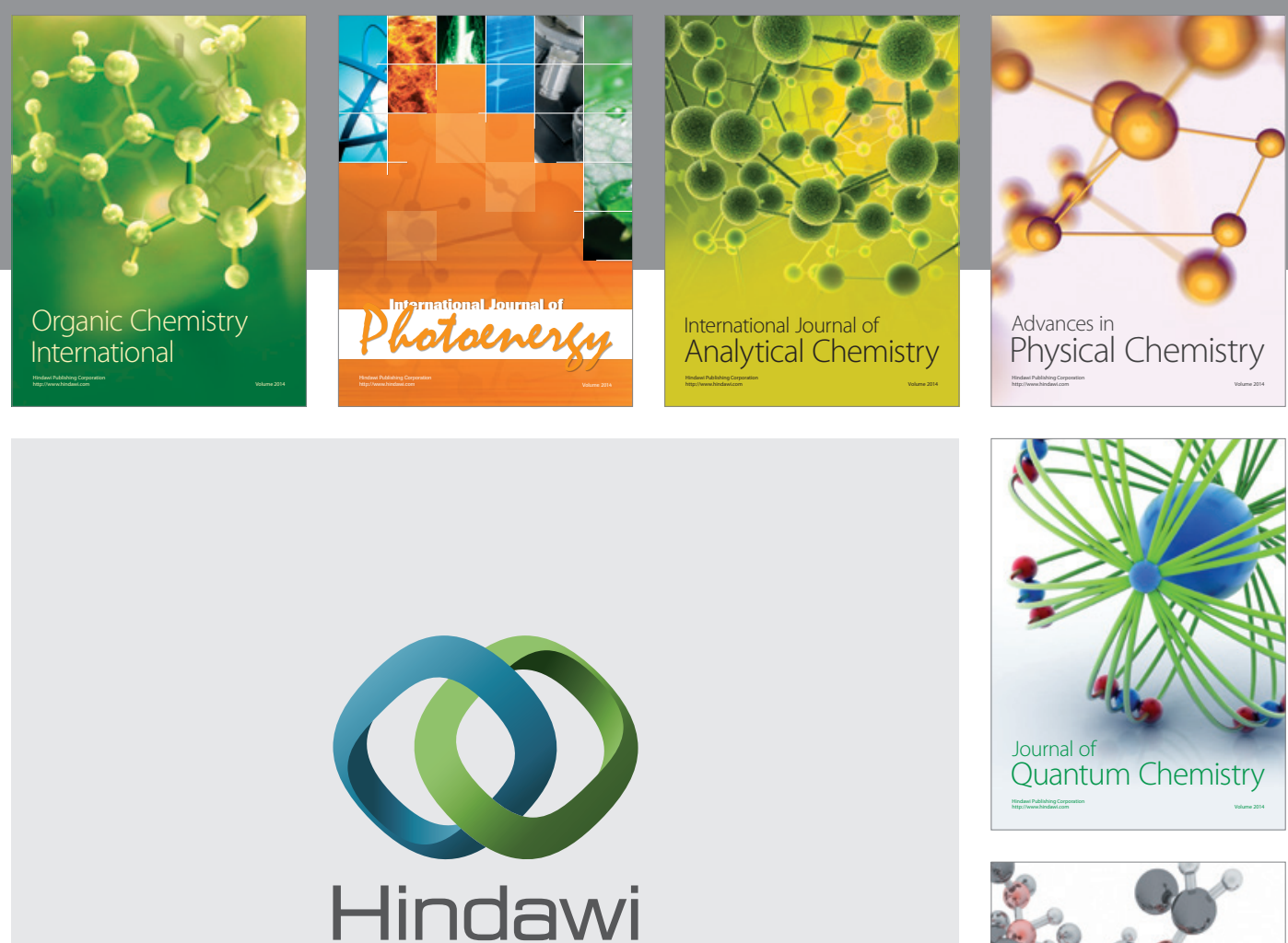

Submit your manuscripts at

http://www.hindawi.com

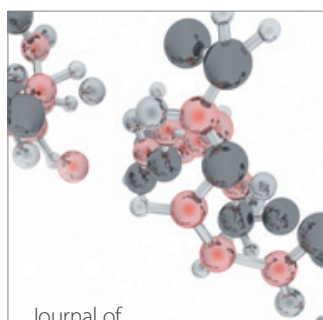

Analytical Methods

in Chemistry

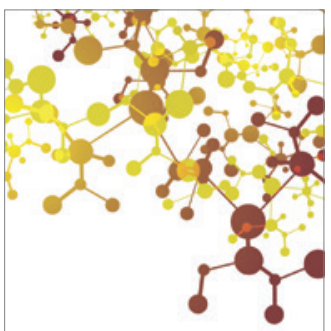

Journal of

Applied Chemistry

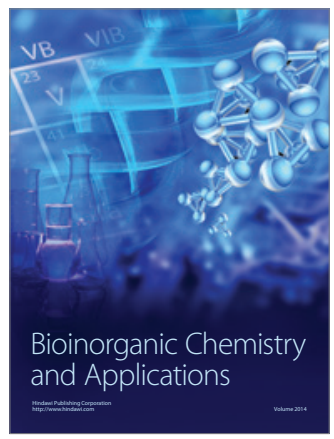

Inorganic Chemistry
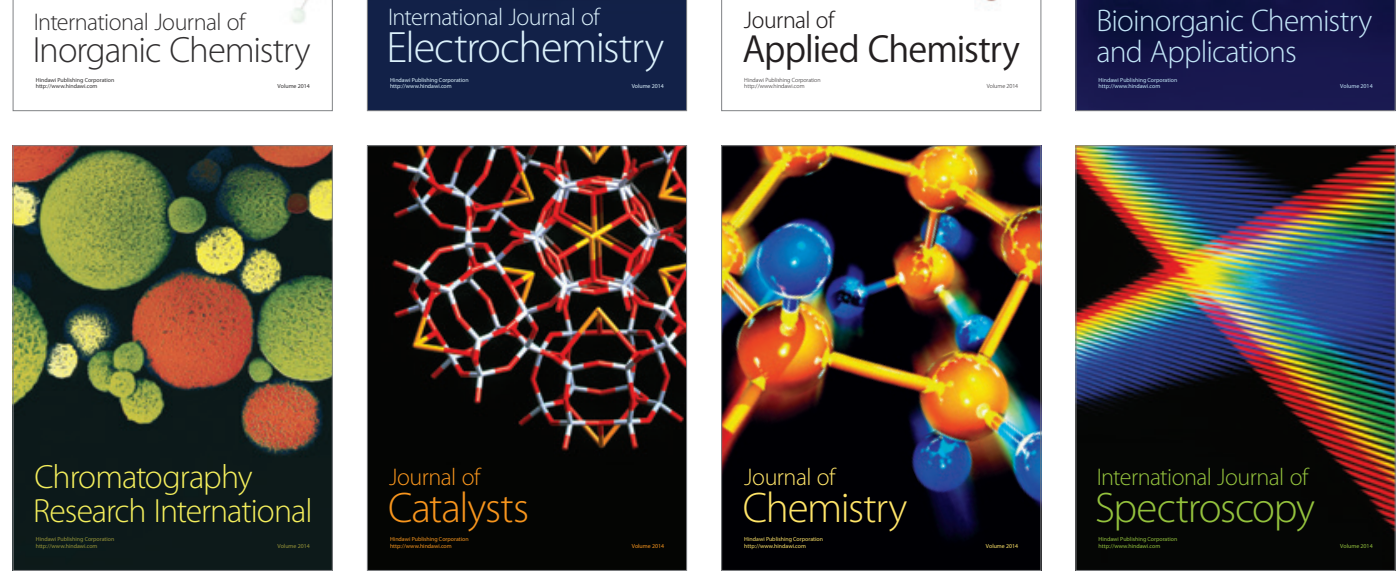